\title{
UNLV|
}

Brookings Scholar Lecture Series

Brookings Mountain West

$4-6-2010$

\section{Creating an Opportunity Society}

\author{
Ron Haskins \\ Center on Children and Families
}

Follow this and additional works at: https://digitalscholarship.unlv.edu/brookings_lectures_events

Part of the Family, Life Course, and Society Commons, Inequality and Stratification Commons, and the Social Policy Commons

\section{Repository Citation}

Haskins, R. (2010). Creating an Opportunity Society.

Available at: https://digitalscholarship.unlv.edu/brookings_lectures_events/3

This Lecture is protected by copyright and/or related rights. It has been brought to you by Digital Scholarship@UNLV with permission from the rights-holder(s). You are free to use this Lecture in any way that is permitted by the copyright and related rights legislation that applies to your use. For other uses you need to obtain permission from the rights-holder(s) directly, unless additional rights are indicated by a Creative Commons license in the record and/or on the work itself.

This Lecture has been accepted for inclusion in Brookings Scholar Lecture Series by an authorized administrator of Digital Scholarship@UNLV. For more information, please contact digitalscholarship@unlv.edu. 


\section{BROOKINGS MOUNTAIN WEST}

BROOKINGS

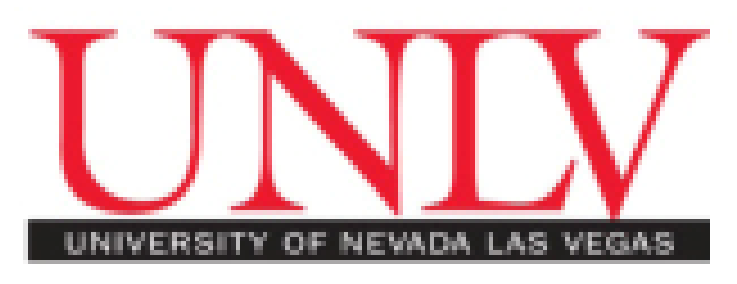




\section{Creating an Opportunity Society}

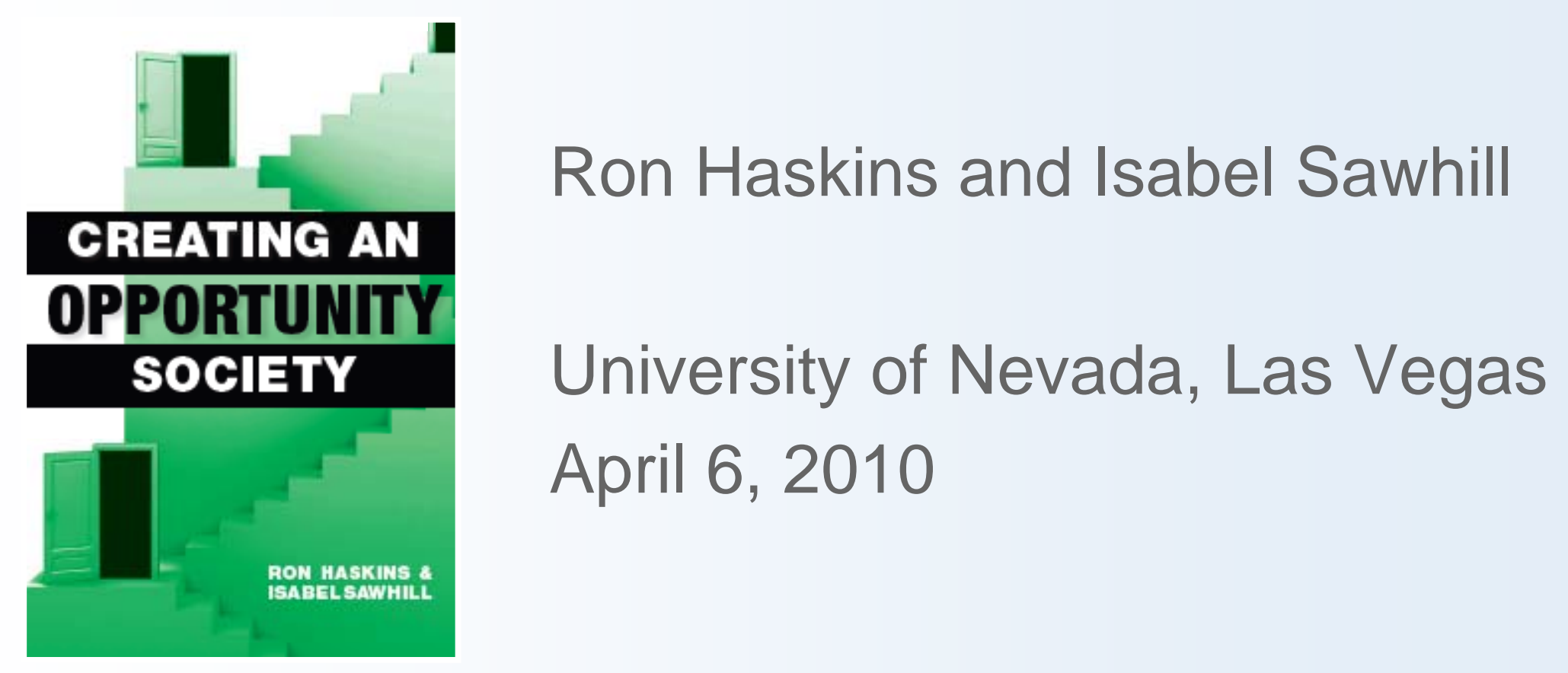


Why Are Poverty and I nequality So Stubborn?

- Work Rates and Wages

- Family Composition

- Education

- Immigration 
Work Rates \& Wages 


\section{Employment-to-Population Ratios for 18 - 30 Year-Old Men, Women, and Black Men, 1962 - 2007}

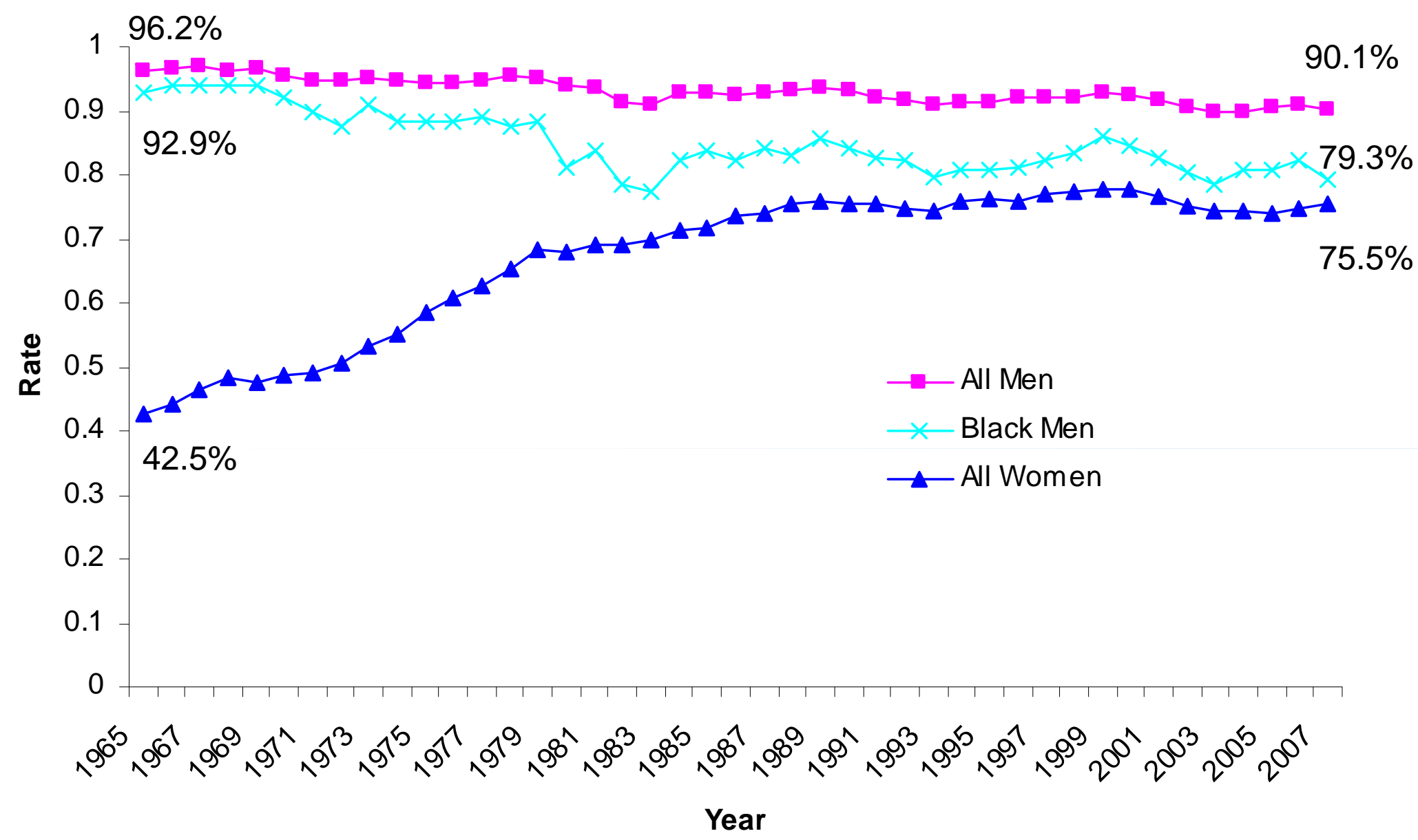

Source: Brookings tabulations of data from the Annual Social and Economic Supplement to the Current Population Survey, 1964-2008.Note: Includes noninstitutionalized civilians ages 25-40. Individuals are considered employed if they worked 14 or more weeks during the year. Because respondents are asked about the number of weeks worked in the previous year, these data are from the CPS of the year after. In other words, the data for 2007 above are actually from the 2008 CPS. 


\section{Employment of Female Family Heads with Children, 1996 - 2009}

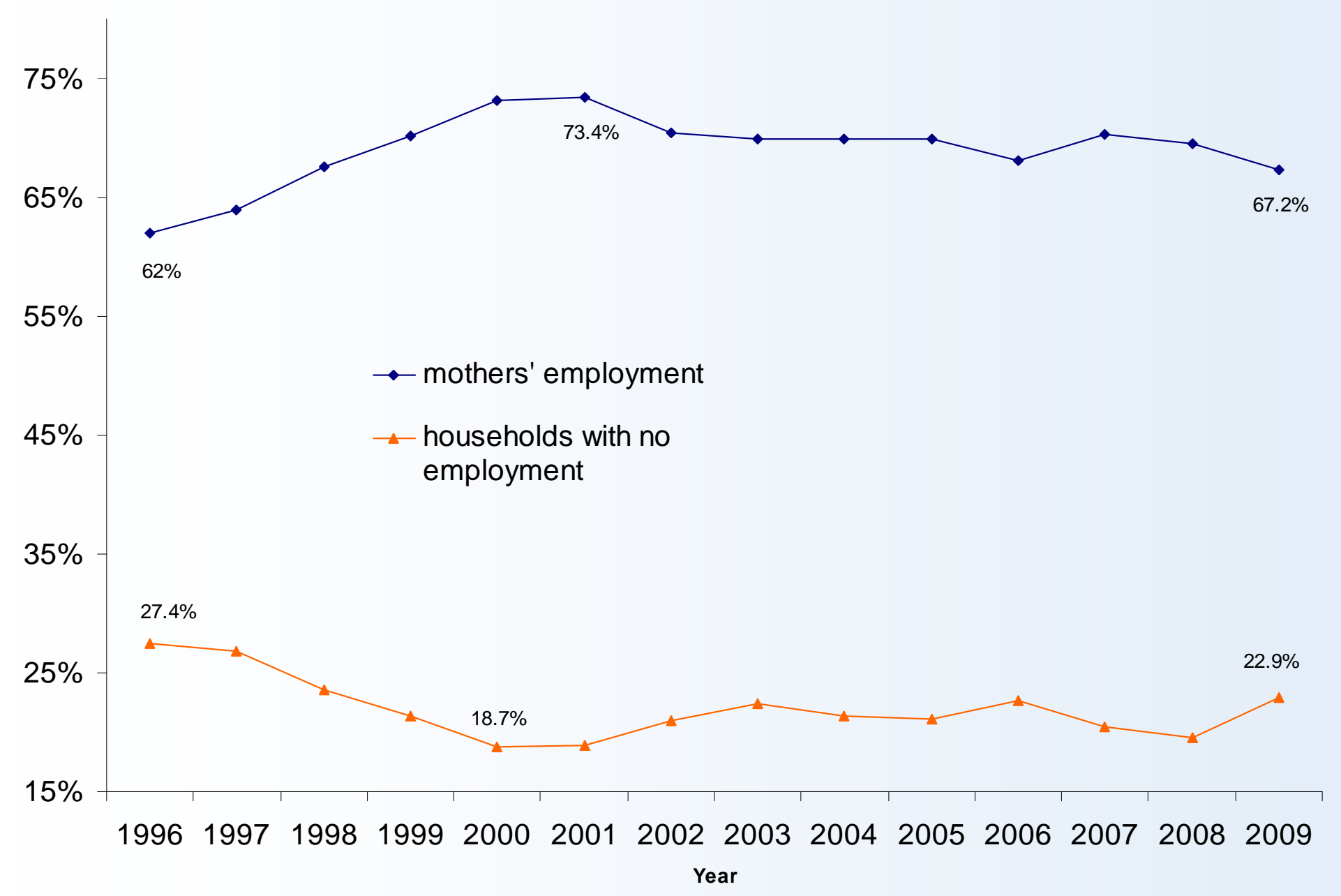

Source: Calculations by Richard Bavier based on the Current Population Survey. Measures are the percentage of all mothers who are employed or live in households with no employment. 
Trend in Real Hourly Wages at Selected Points in 140\% - U.S. Wage Distribution, 1979 - 2007

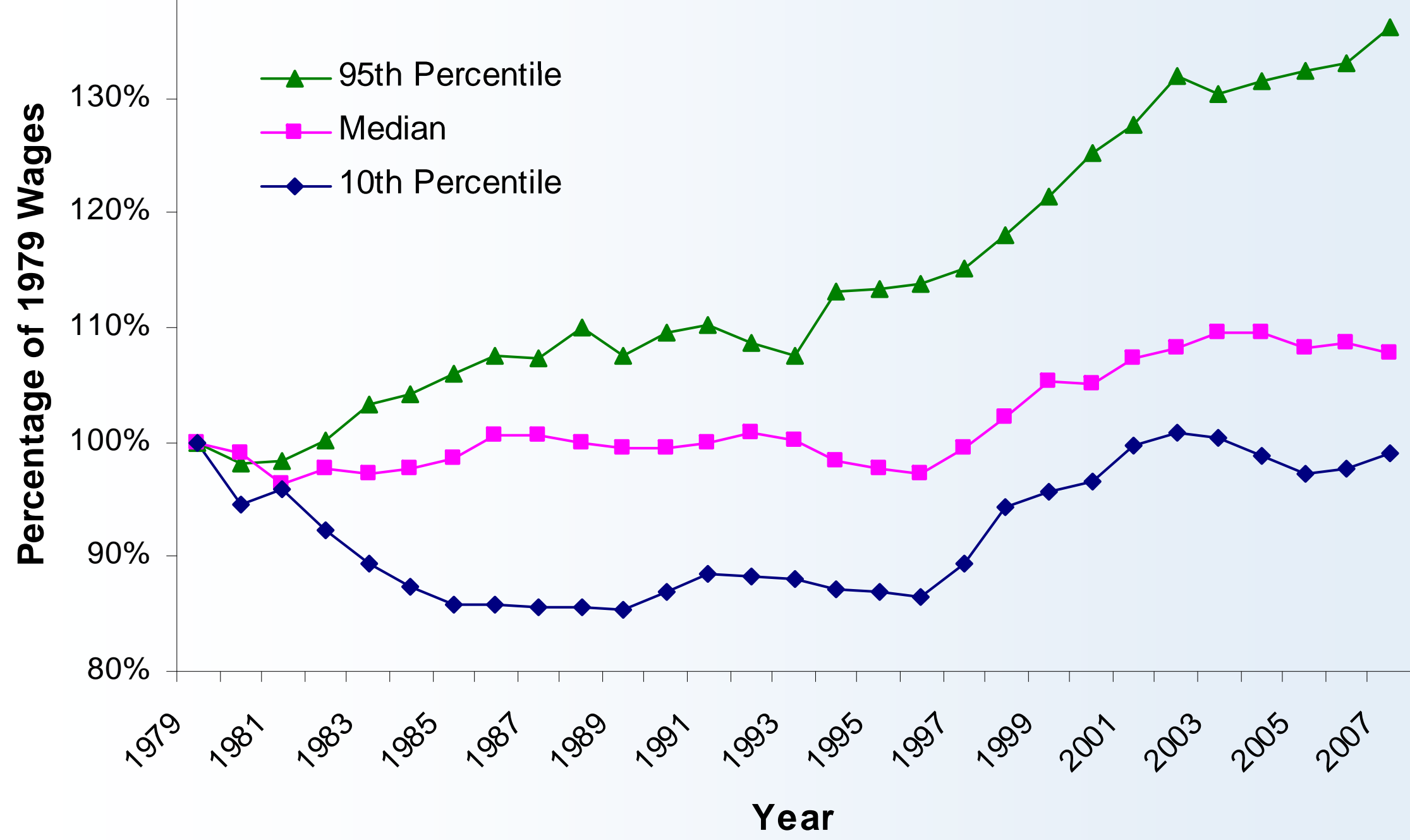

Source: The State of Working America 2008-10, Table 3.5. Note: Hourly wages based on tabulations of Current Population Survey files, converted to constant dollars using the CPI-U-RS. 
Family Composition 


\section{Birth Rate and Percent of Births to Unmarried Women, 1940 - 2007}

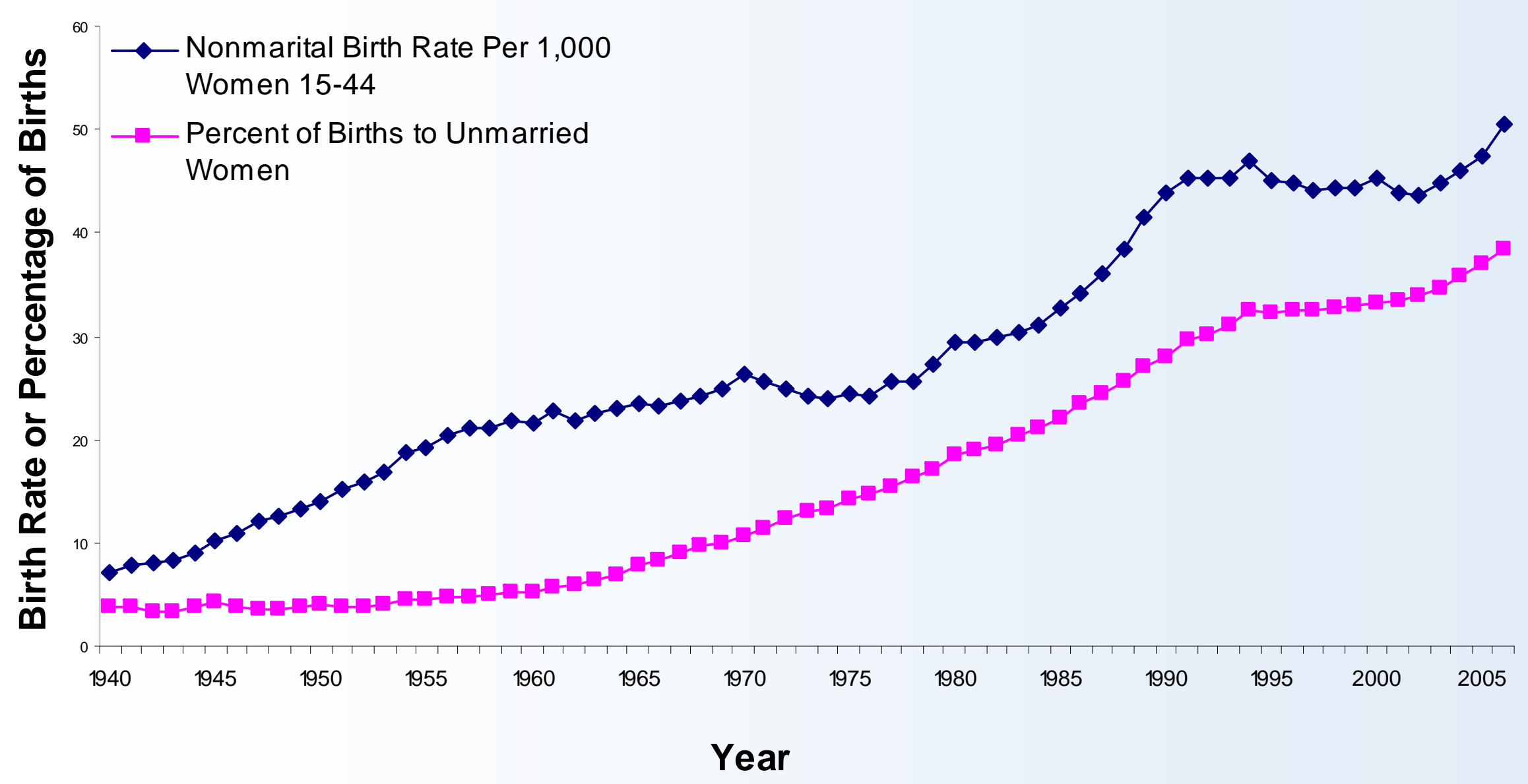




\section{Differences in Non-marital Births by Mother's Education and Ethnicity, 1968 - 2006 or 2008}

Differences: Education

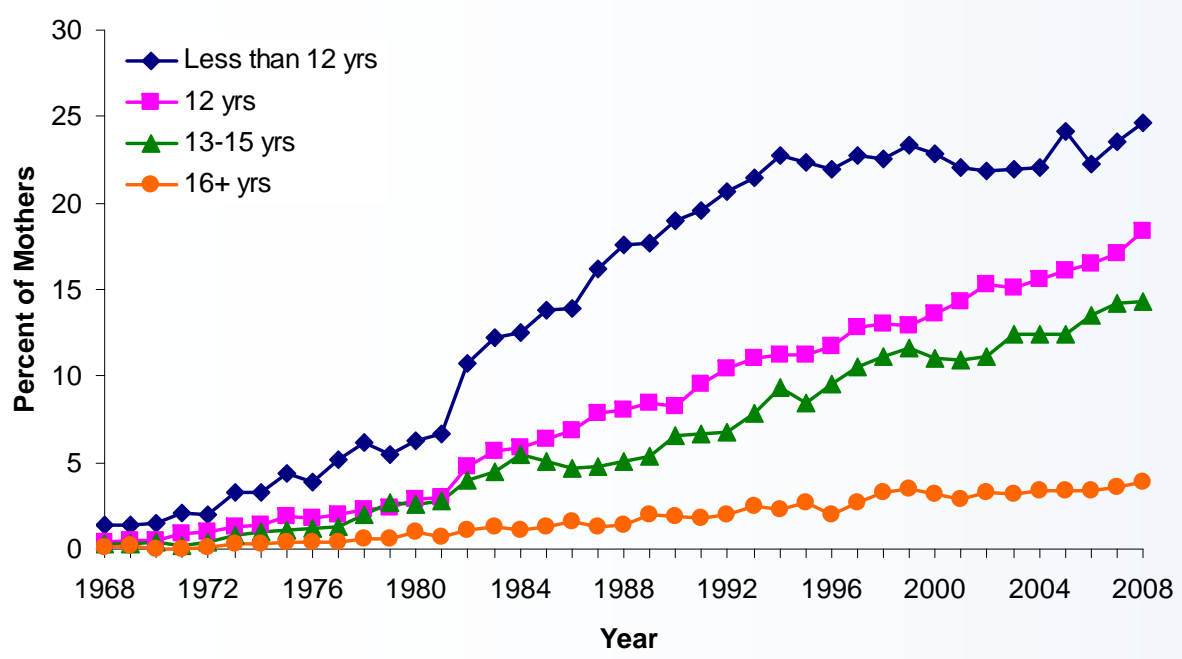

Differences: Ethnicity

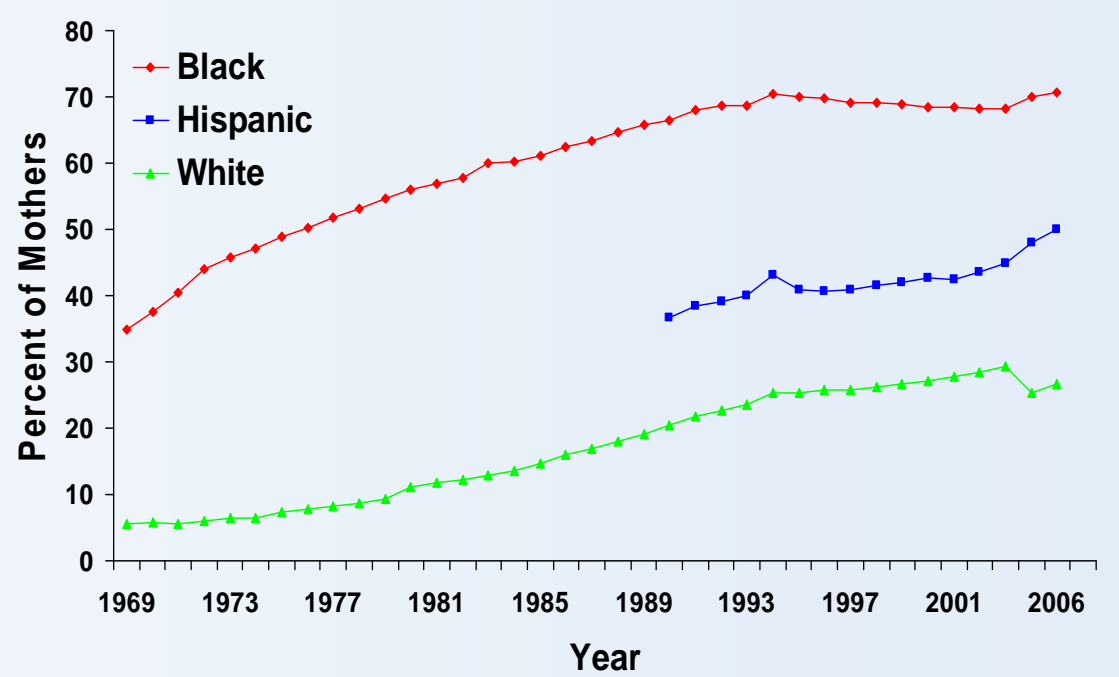

Source: (Education) Authors' tabulations from the March Current Population Survey; (Ethnicity) National Center for Health Statistics, Table 1-17 Number and Percent of Births to Unmarried Women, by Race and Hispanic Origin: United States, 1940-2000; National Vital Statistics Reports, Vol. 56, No. 7, December 5, 2005 accessed at http://www.cdc.gov/nchs/data/nvsr/nvsr56/nvsr56_07.pdf

Note: 2004 Unavailable 


\section{Poverty in Female-Headed and Married-Couple Households with Children, 1974 - 2008}

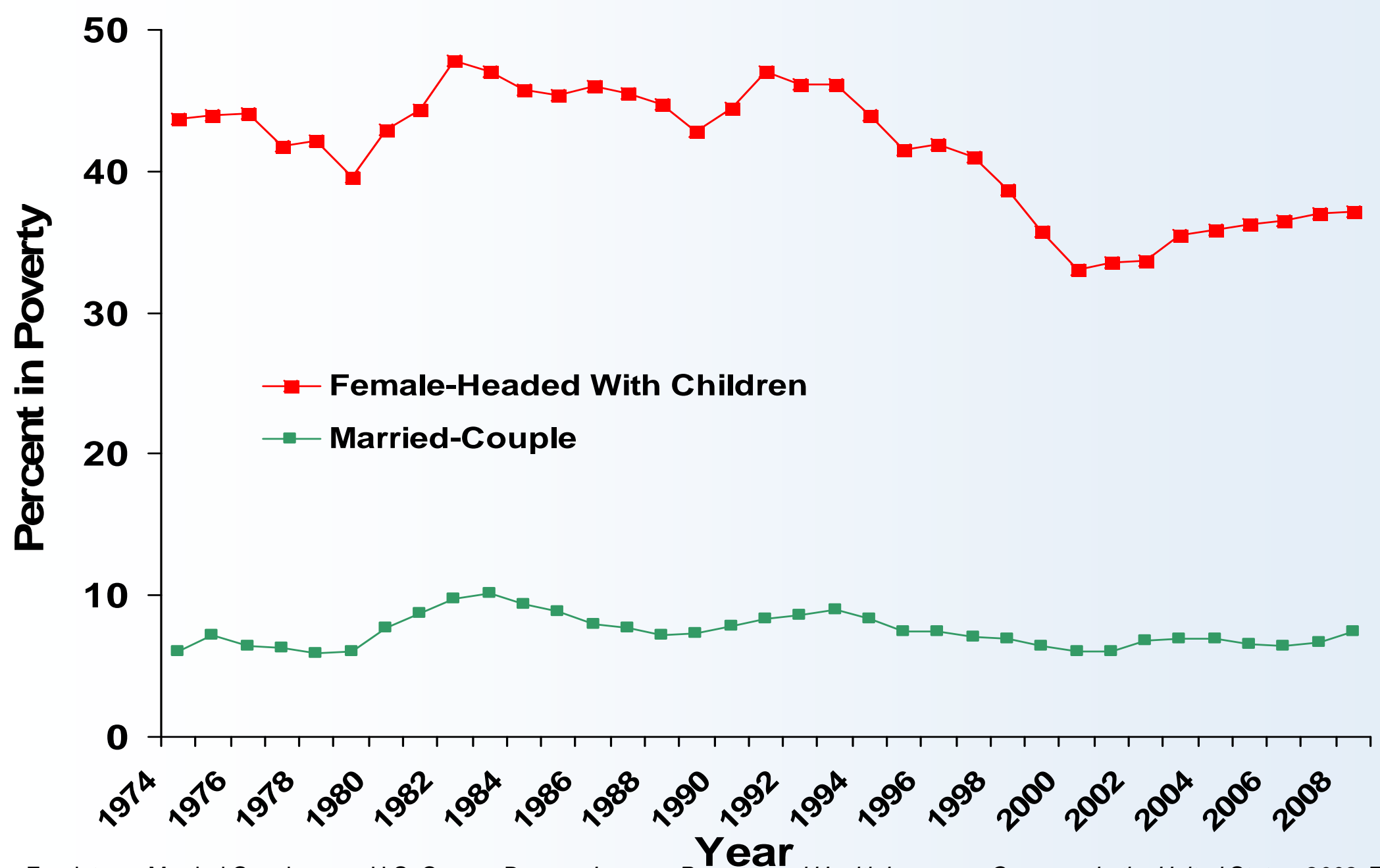

Source: For data on Married Couples, see U.S. Census Bureau, Income, Poverty, and Health Insurance Coverage in the United States: 2008, Table B-3; for data on Female-Headed Households with Children, see: http://www.census.gov/hhes/www/poverty/histpov/famindex.html, Table 4. 


\section{Percent of Children Living in Single-Parent Families, 1970 - 2008}

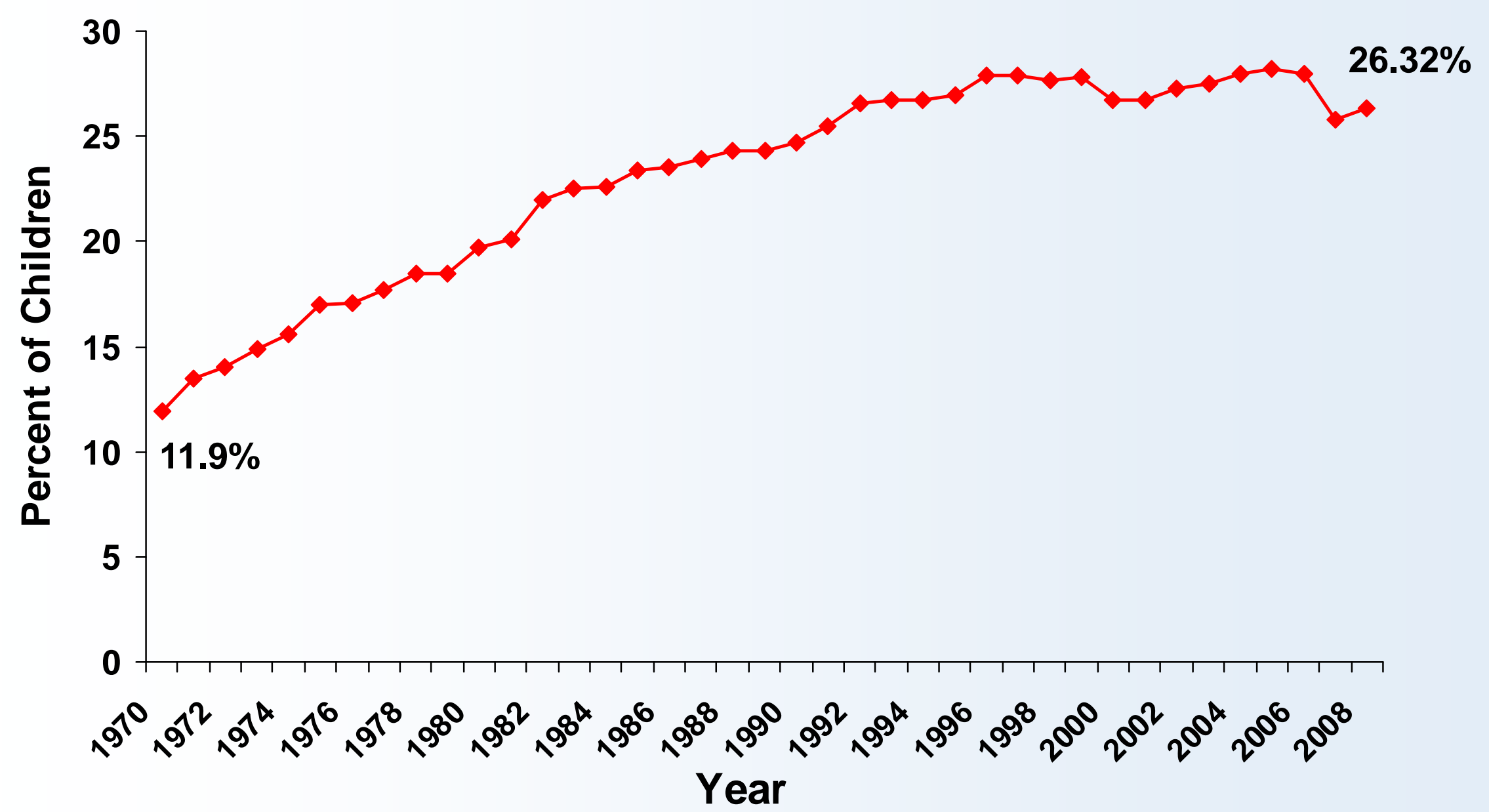

*2007 and 2008 are estimates produced using PELNMOM and PELNDAD, the new parent variables introduced in 2007.

Source: U.S. Census Bureau, Current Population Survey, March and Annual Social and Economic Supplements, 2007 and earlier data available at http://www.census.gov/population/socdemo/hh-fam/ch1.xls. 
Education 


\section{Median Family I ncome of Adults Ages 30-39 with Various Levels of Educational Achievement, 1965 - 2007}

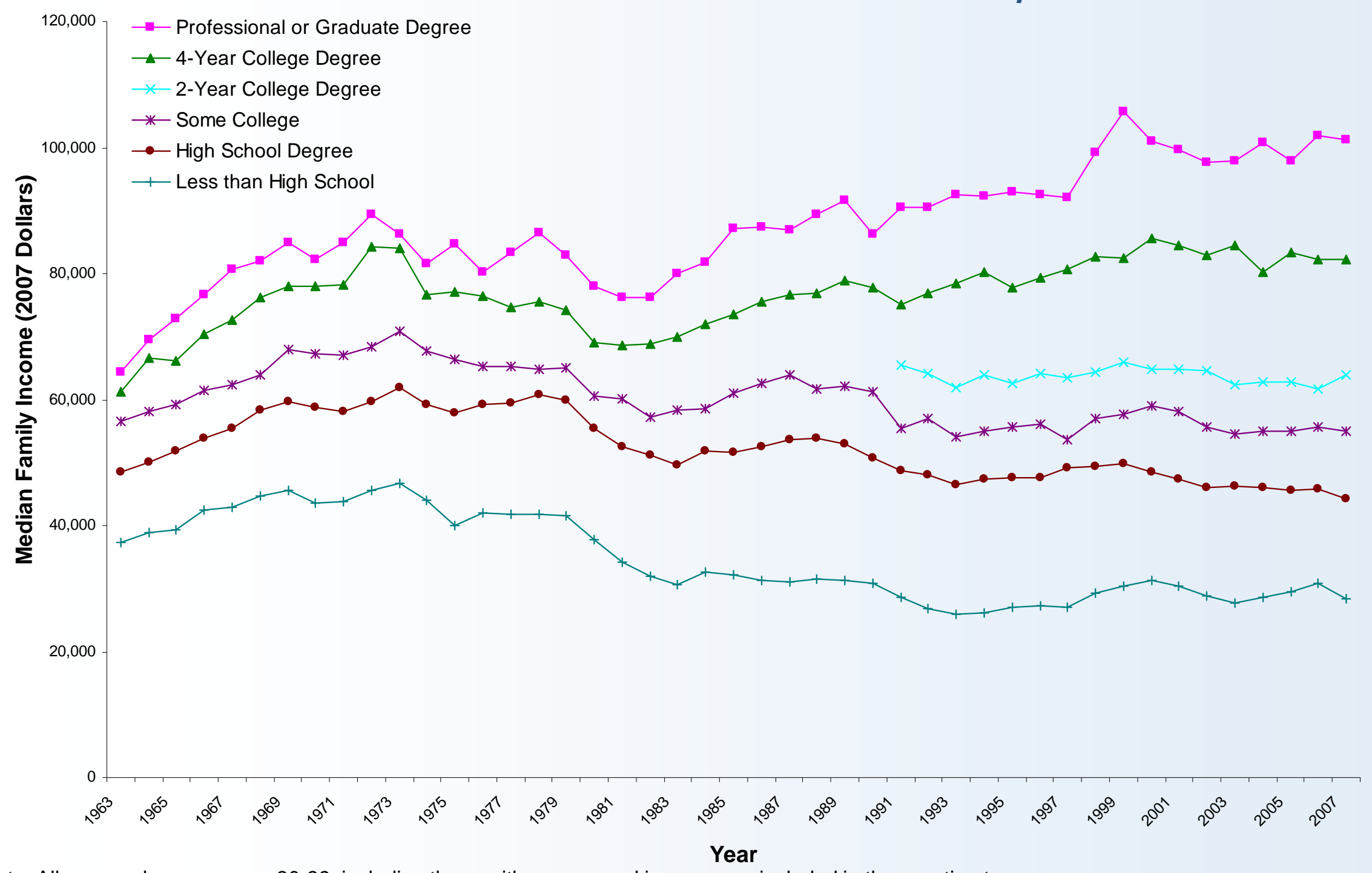

Note: All men and women ages 30-39, including those with no personal income, are included in these estimates. Source: Brookings tabulations of data from the Annual Social and Economic Supplement to the CPS, 1965-2006. 


\section{High School Graduation Rate by Gender and Ethnic Group, 1900 - 2000}
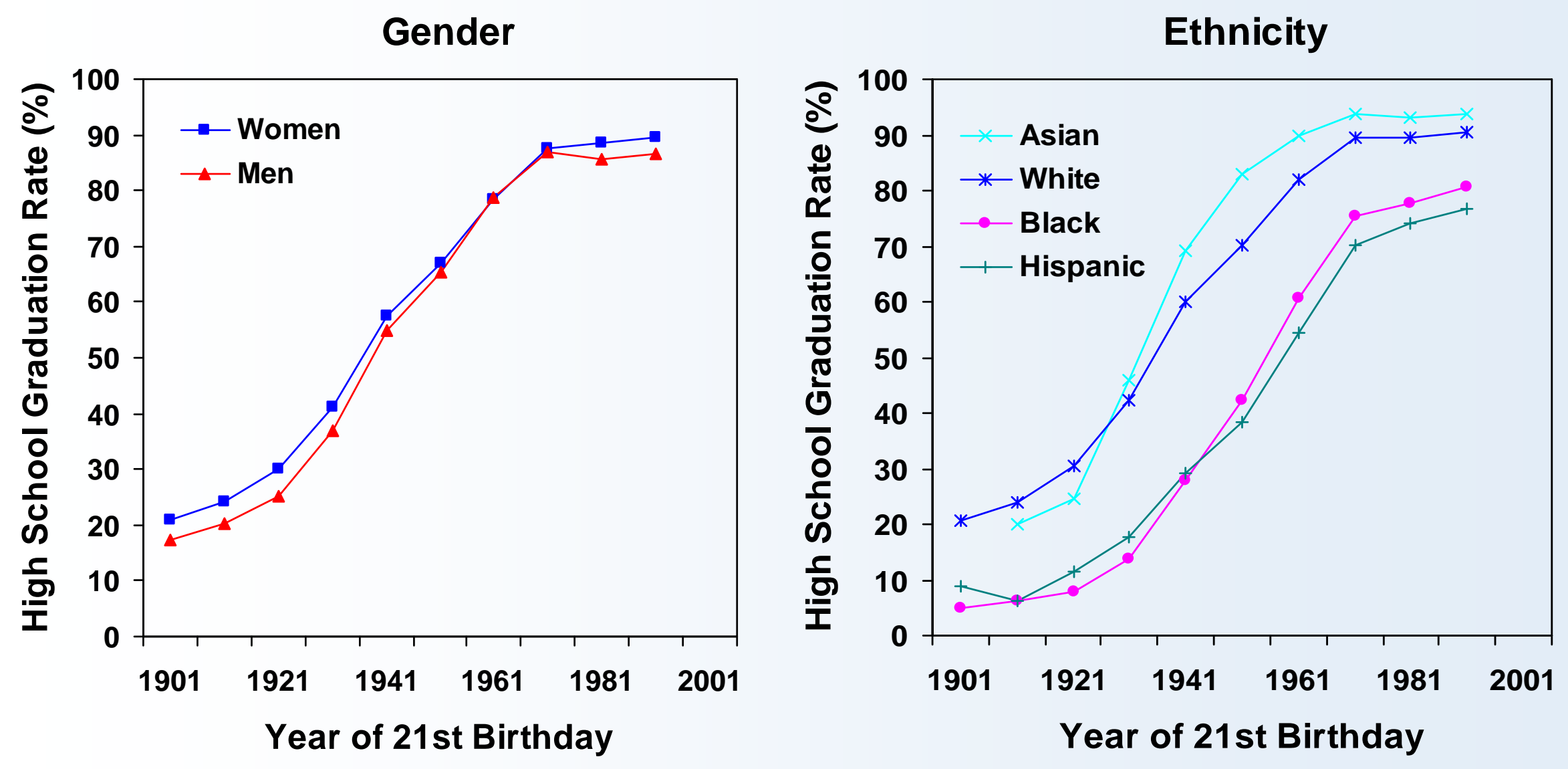


\section{College Graduation Rate by Gender and Ethnicity, 1900-2000}
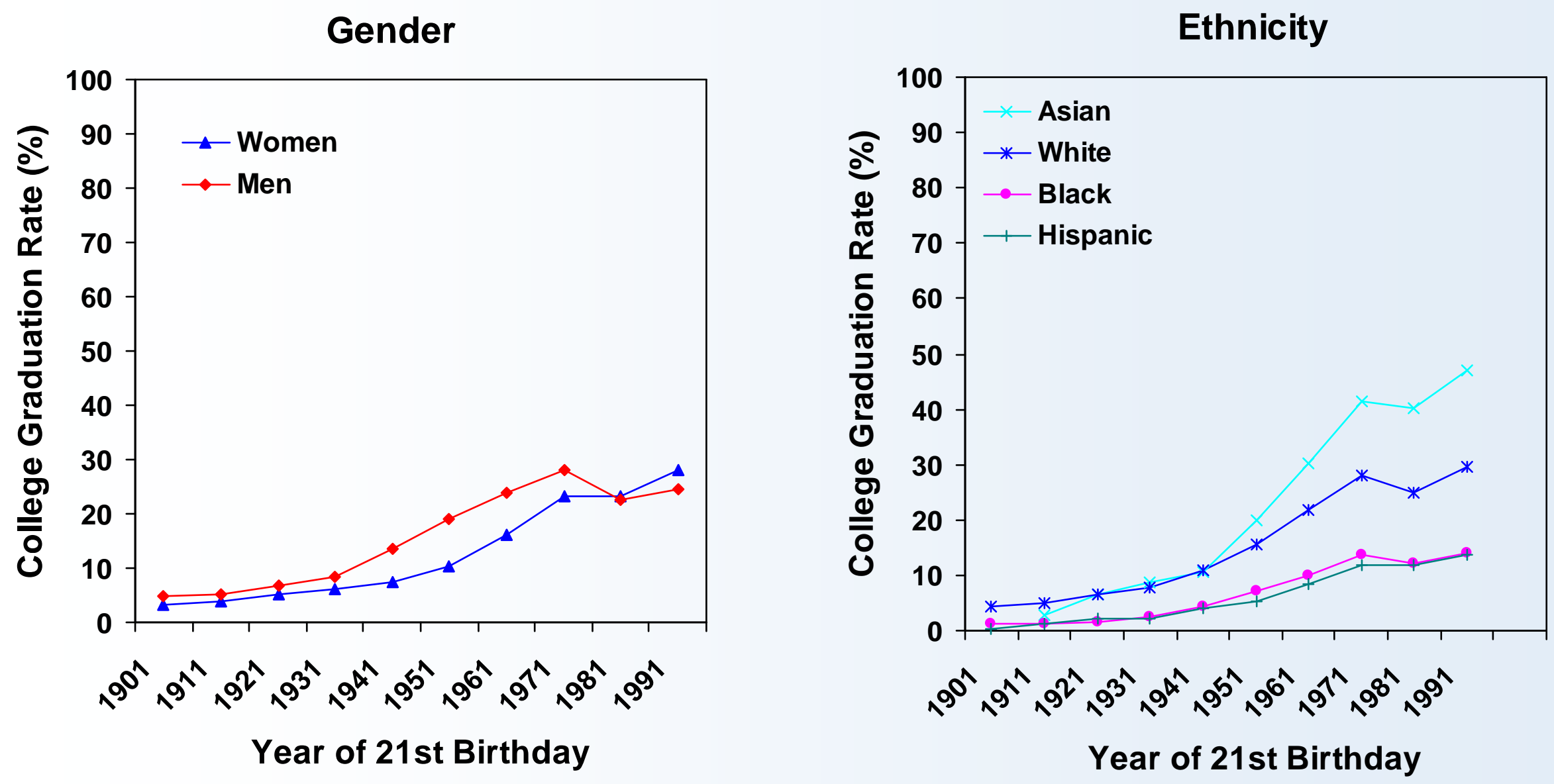


\section{Reading Scores for 9, 13, and 17 Year Olds, 1974-2008}

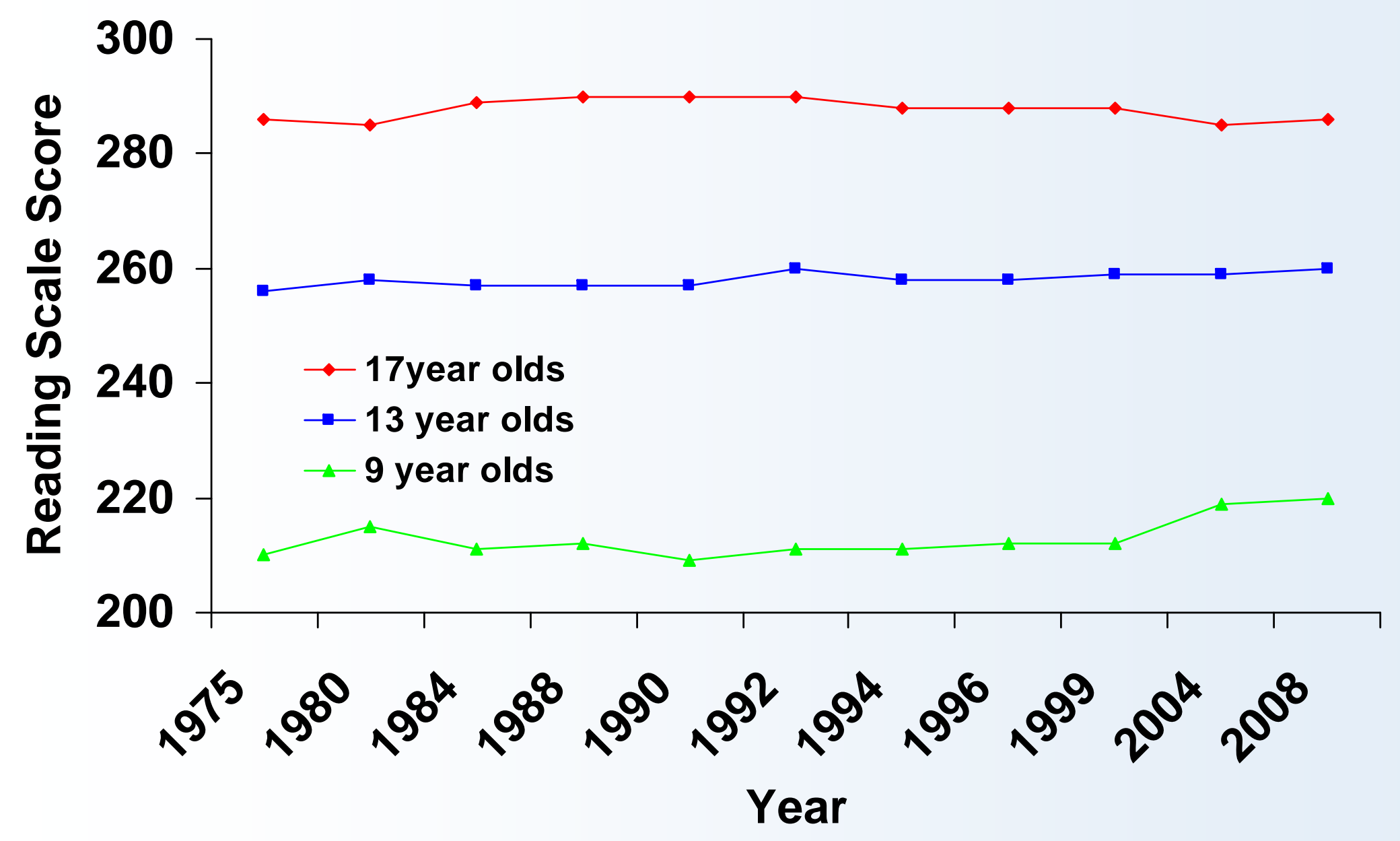




\section{Poor Kids Less Likely to Enroll in College; Even Less Likely to Graduate}

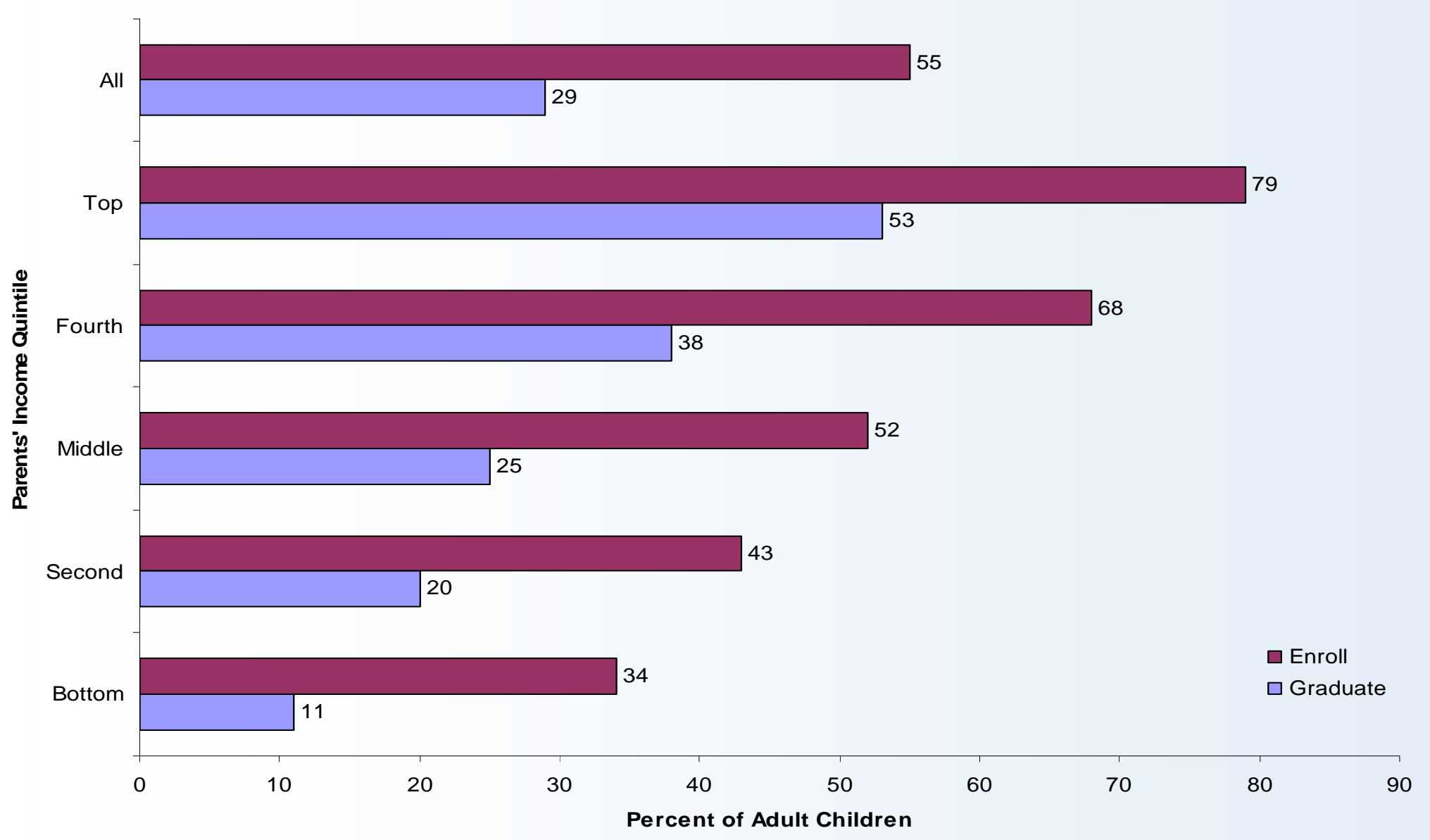




\section{Annual Number of Legal U.S. I mmigrants by Decade and Region of Origin, 1960-2005}

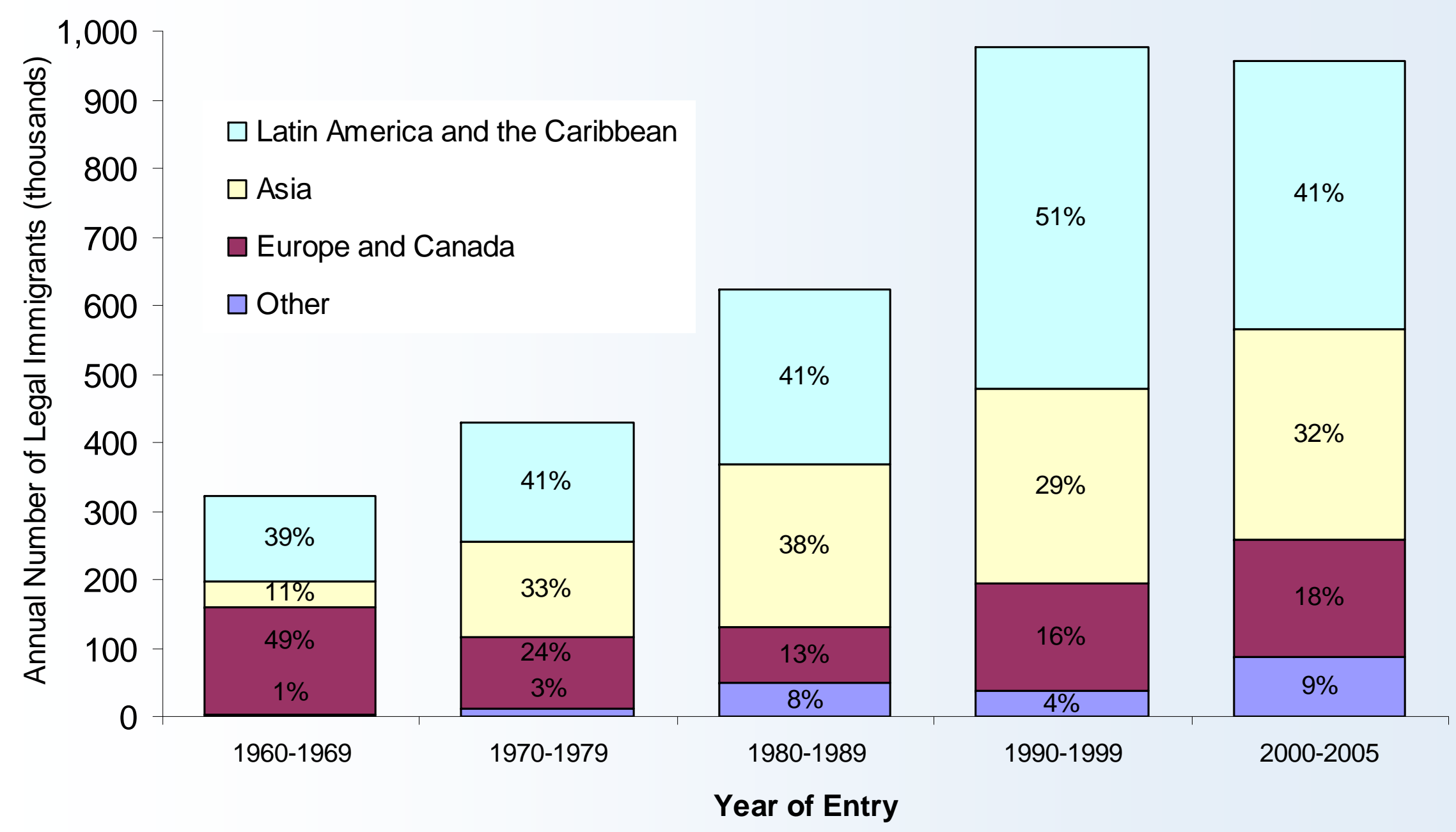

Source: Martin and Midgley, 2006, p. 3. 
First Generation Age-Adjusted Wages Relative to Wages of Non-I mmigrants, 1940, 1970, 2000

10

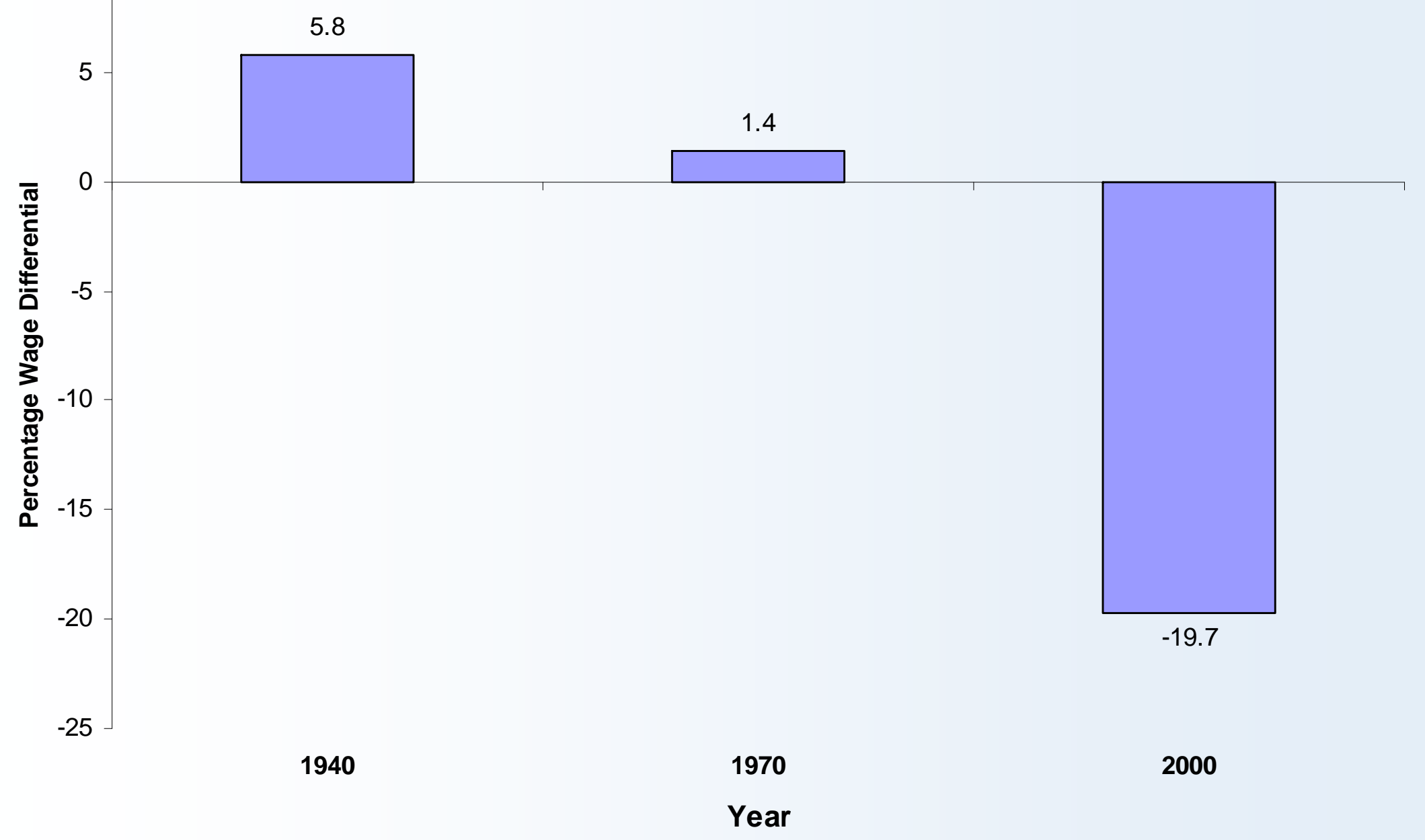




\section{Second Generation Age-Adjusted Wages Relative to Wages of Non-I mmigrants, 1940, 1970, 2000}

20

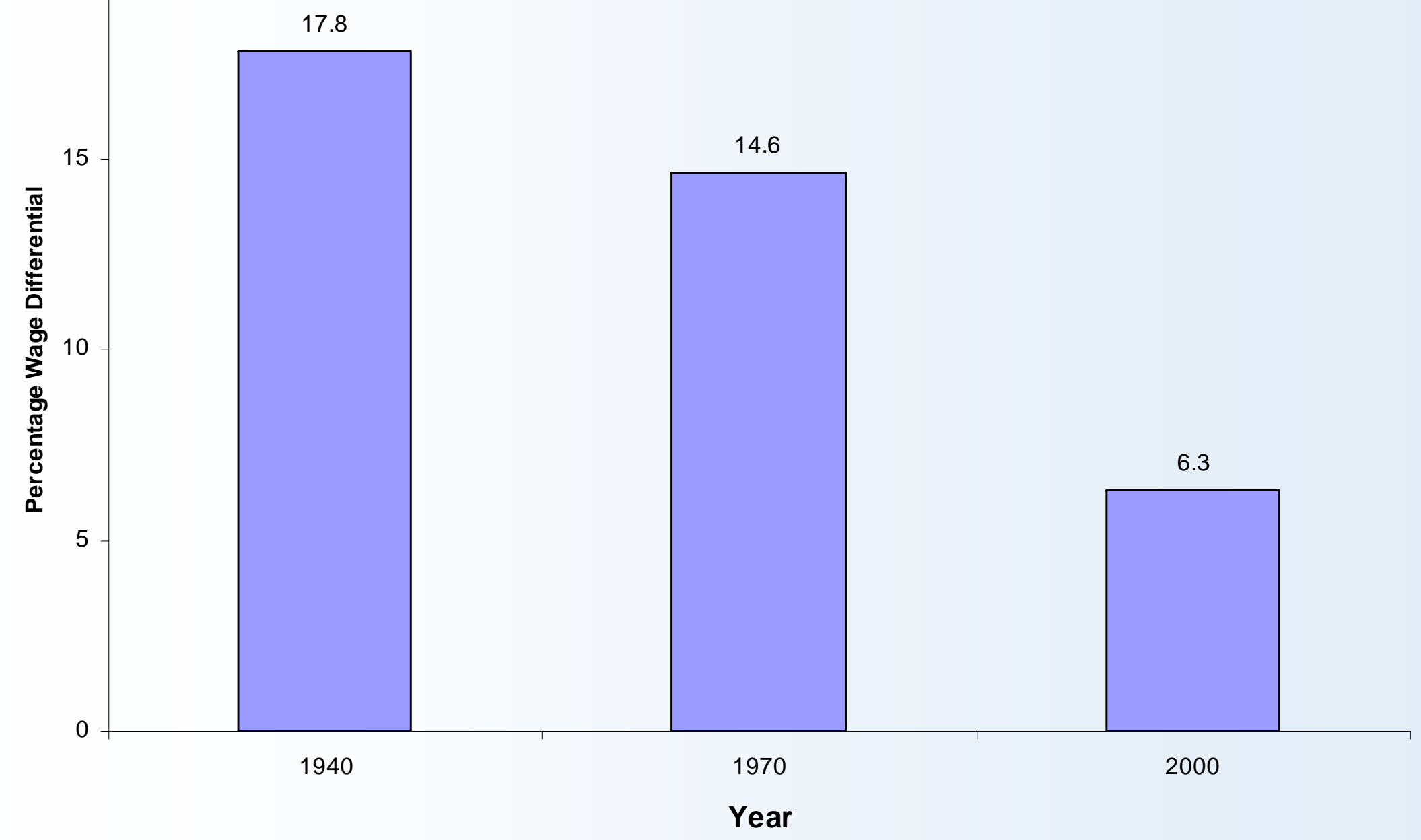




\section{First and Second Generation Age-Adjusted Wages Relative to Wages of Non-I mmigrants}

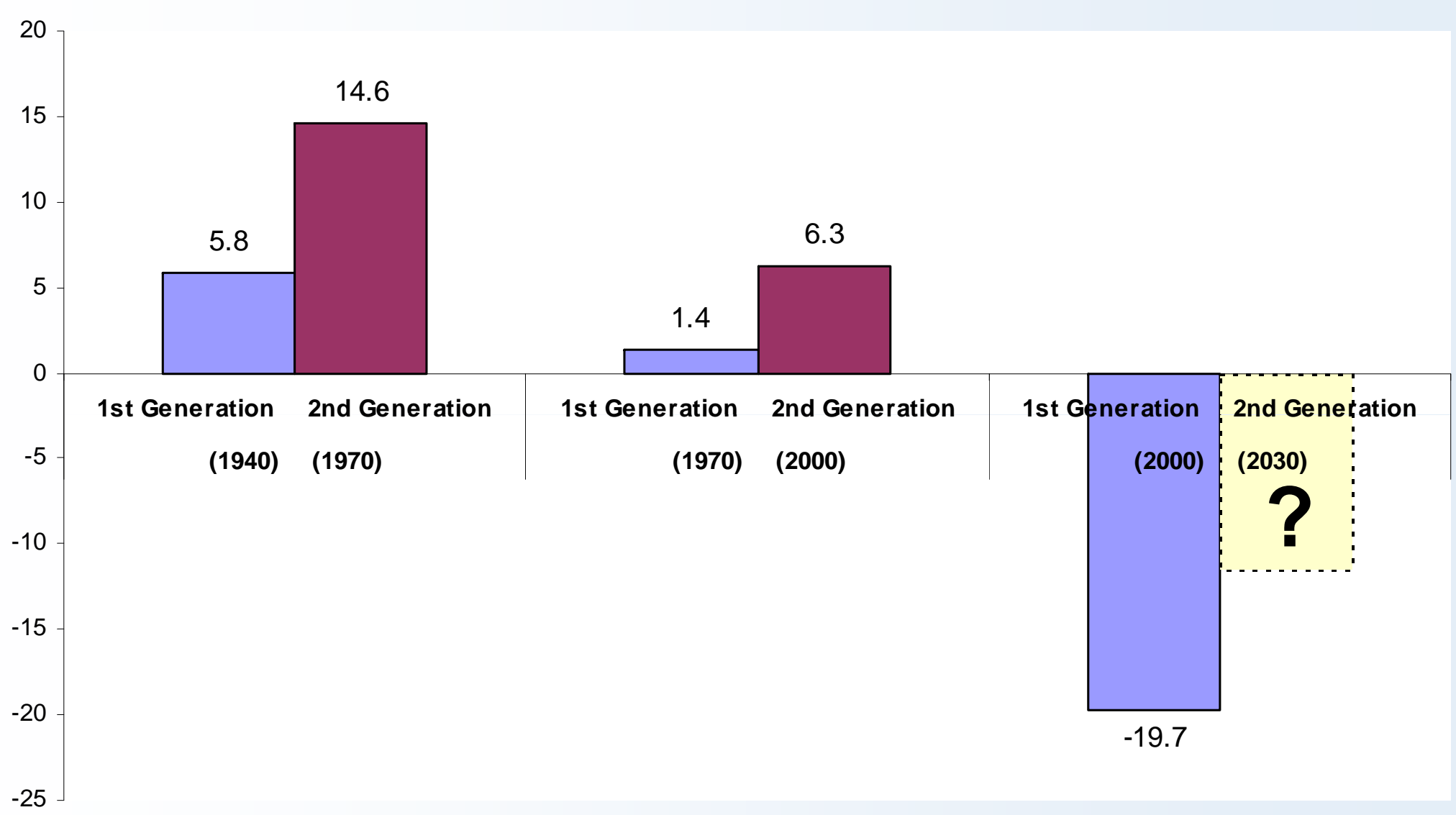

Generation and Year 


\section{Opportunity and Mobility}




\section{Family Background Matters}

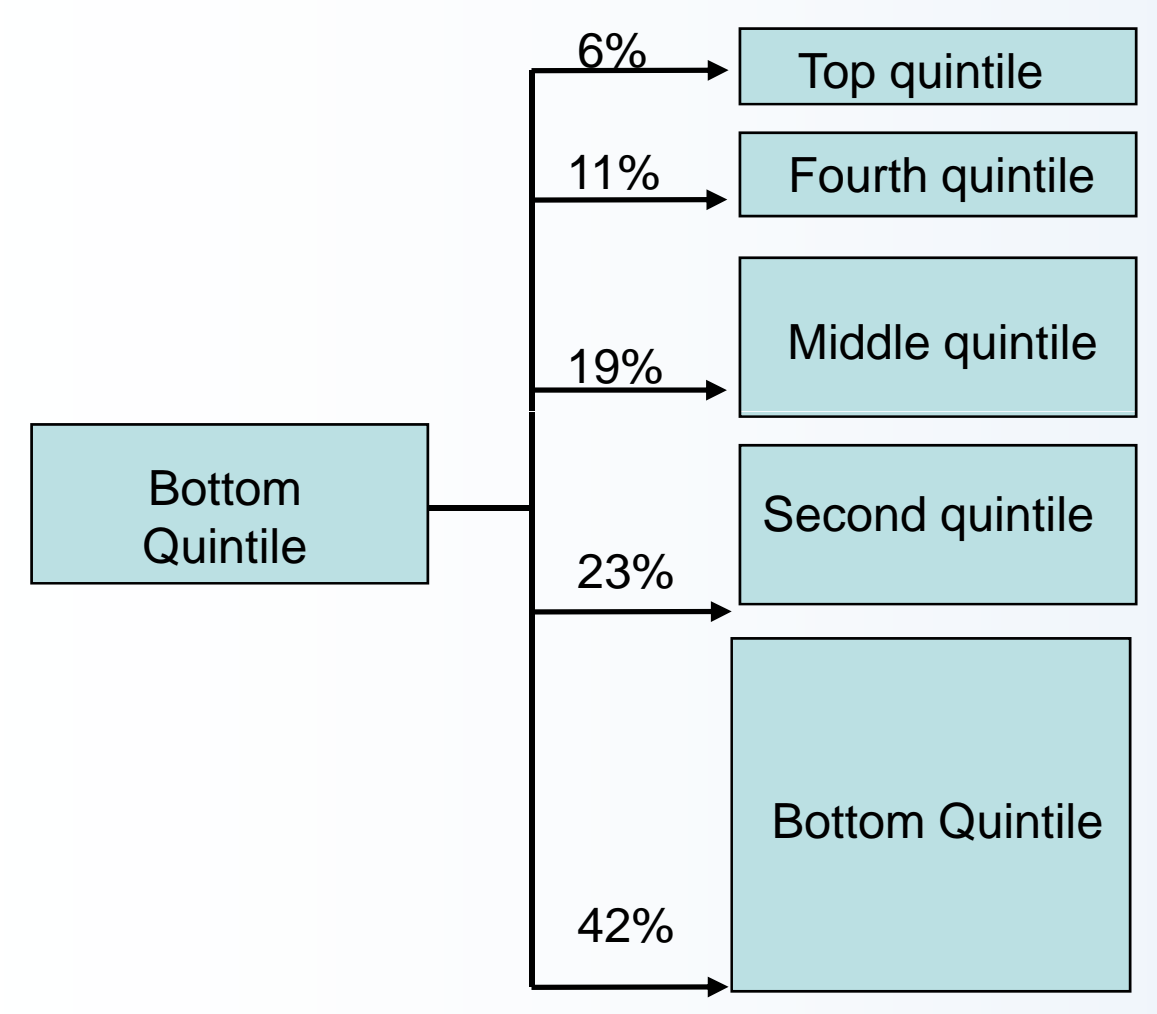

Only 6 percent of those born

into a family in the bottom

quintile climb to the top quintile

as adults.

On the other hand, 42 percent of those born into a family in the bottom quintile remain in this quintile as adults.

Source: Julia B. Isaacs, Isabel V. Sawhill, and Ron Haskins. Getting Ahead or Losing Ground: Economic Mobility in America (The Brookings Institution and The Pew Economic Mobility Project, 2008), figure 4 p 19.

Note: Family incomes are five-year averages from the Panel Study of Income Dynamics for 1967-1971, when parents were 41-years-old on average, and again in 1995-2002 when their adult children were 39-years-old on average. 


\section{Family Background Matters}

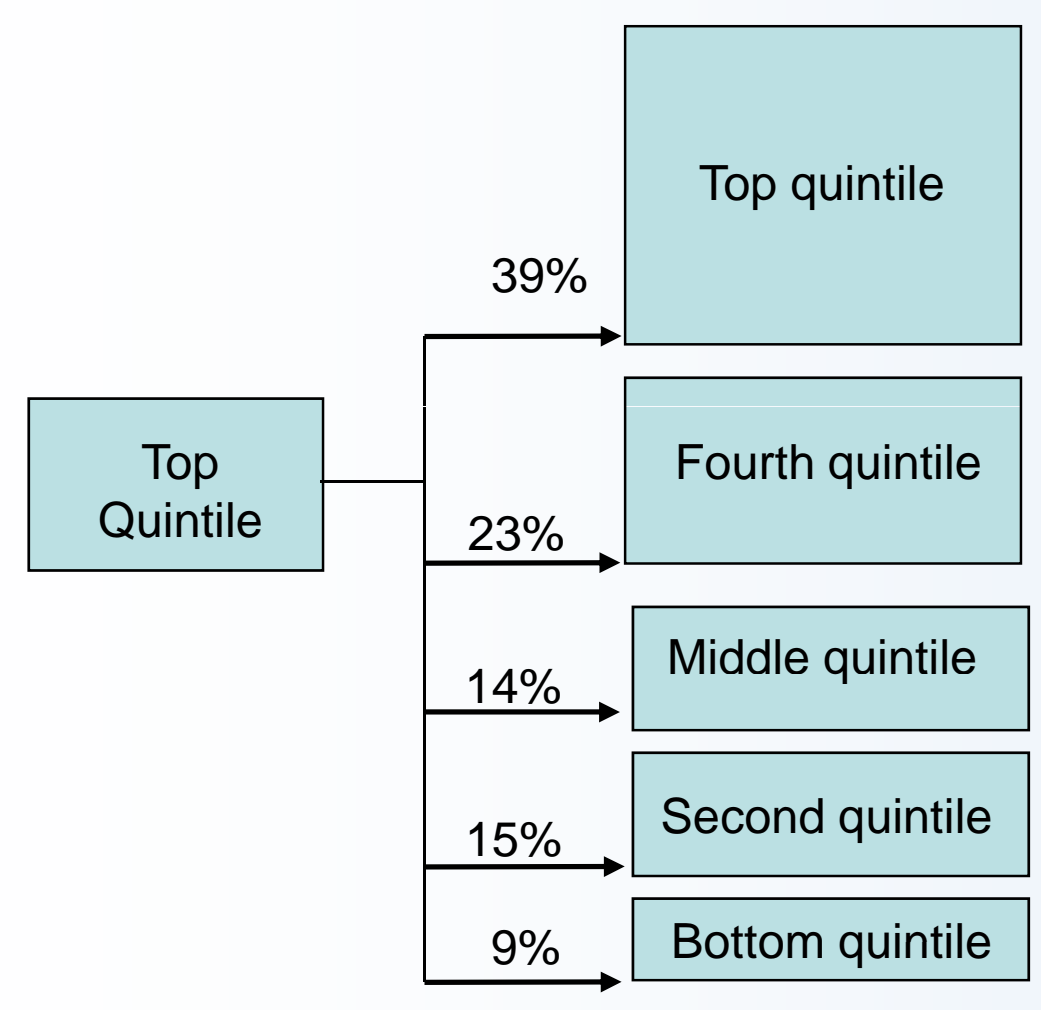

Of those born into a family in the top quintile, 39 percent remain in the top quintile as adults.

Only 9 percent of those born into a family in the top quintile fall to the bottom quintile as adults.

Source: Julia B. Isaacs, Isabel V. Sawhill, and Ron Haskins. Getting Ahead or Losing Ground: Economic Mobility in America (The Brookings Institution and The Pew Economic Mobility Project, 2008), figure 4 p 19.

a. Family incomes are five-year averages from the Panel Study of Income Dynamics for 1967-1971, when parents were 41-years-old on average, and again in 1995-2002 when their adult children were 39-years-old on average. 


\section{Chances of Getting Ahead for Adult Children with and} without a College Degree from Families of Varying I ncome

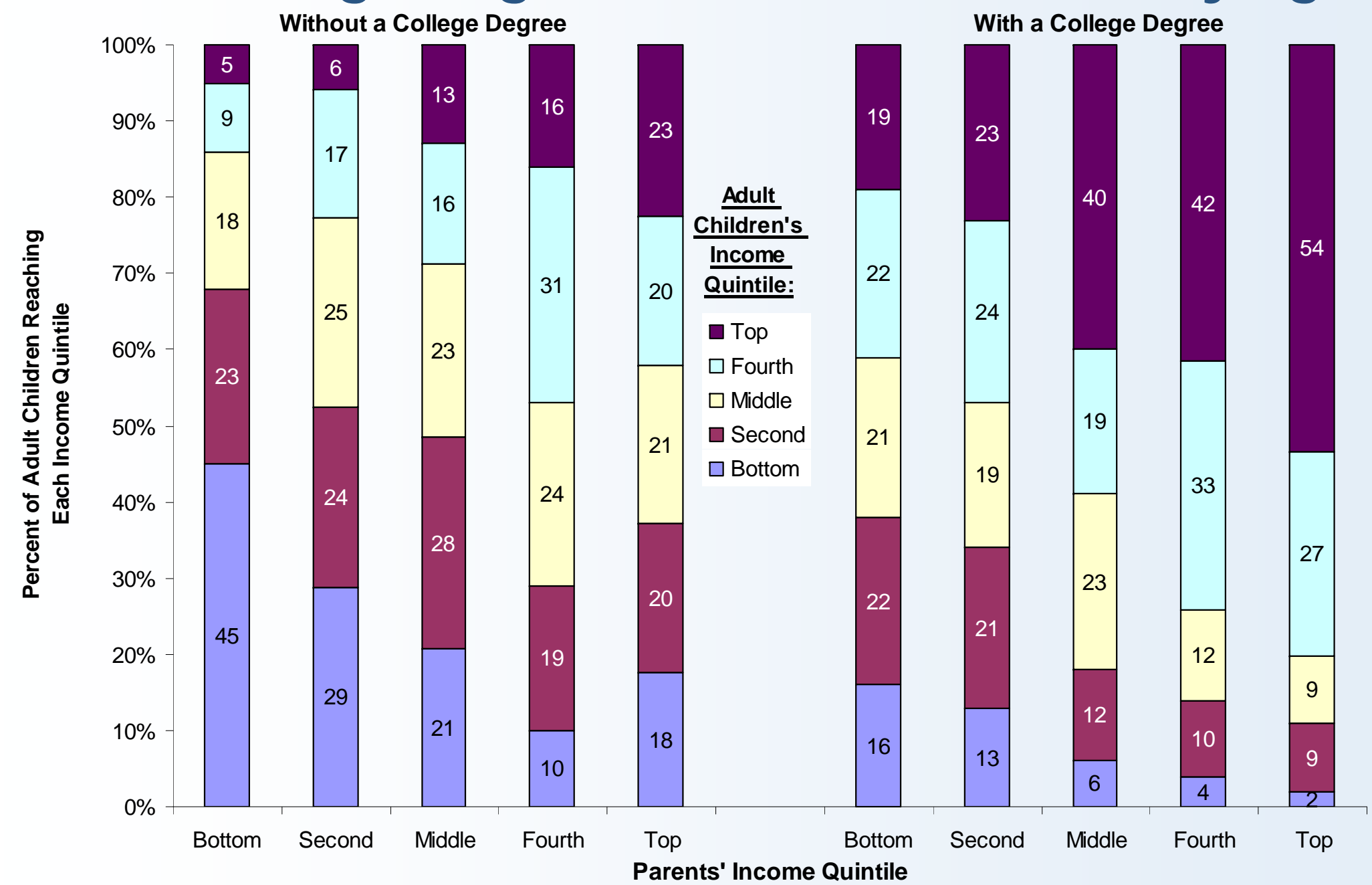

Source: Brookings tabulations using data from the Panel Study of Income Dynamics; See Ron Haskins, "Education and Economic Mobility" in Getting Ahead or Losing Ground: Economic Mobility in America, edited by Julia Isaacs, Isabel Sawhill, and Ron Haskins (Washington, D.C.: Brookings-Pew Economic Mobility Project, 2008), p.91-104. 


\section{Chances of Black Children Getting Ahead}

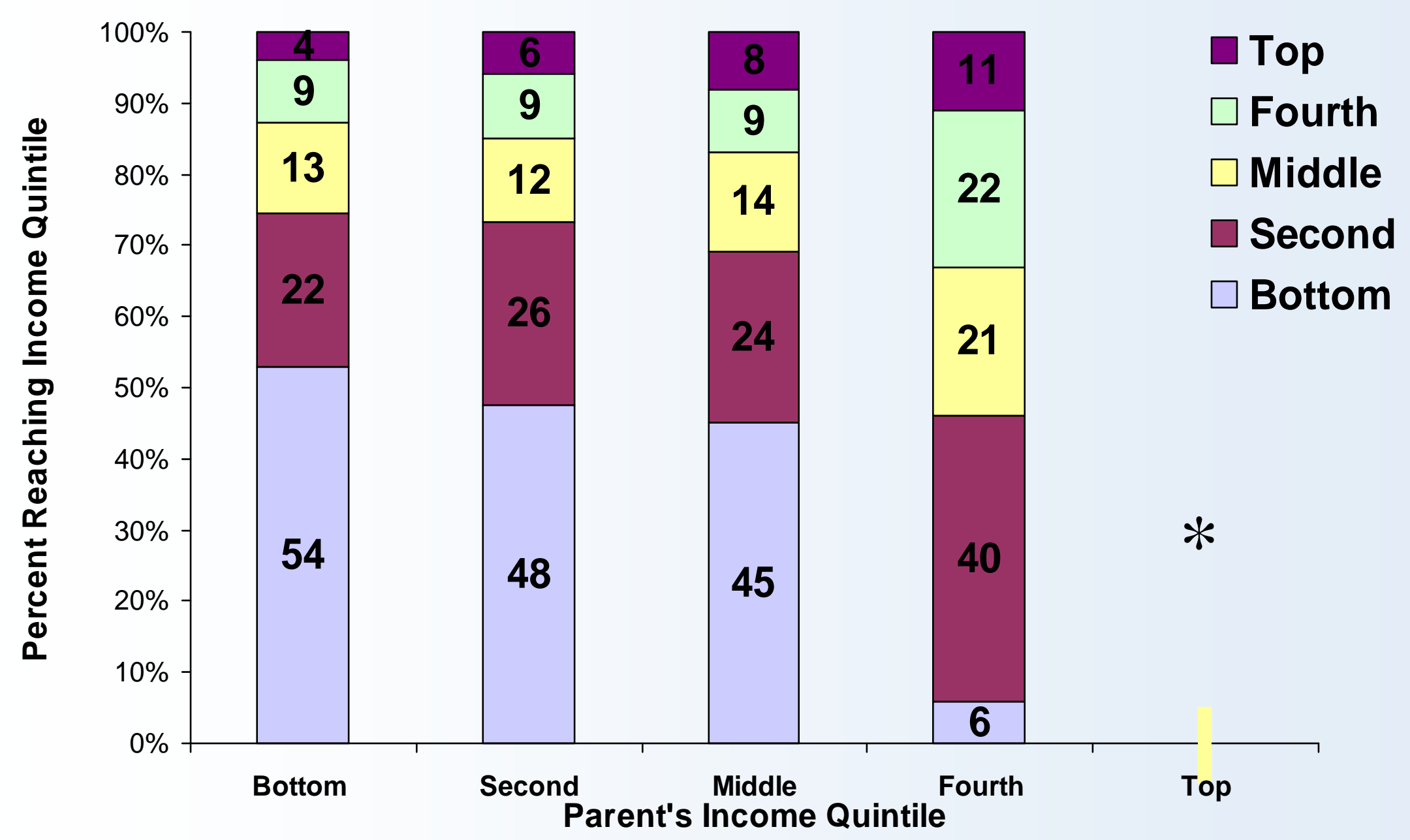

Source: See Julia Isaacs, "Economic Mobility of Black and White Families" in Getting Ahead or Losing Ground: Economic Mobility in America, edited by Julia Isaacs, Isabel Sawhill, and Ron Haskins (Washington, D.C.: Brookings-Pew Economic Mobility Project, 2008), Figure 6. ${ }^{*}$ To few observations to estimate. 


\section{Substantial I ndividual Mobility over the Life Course}

\begin{tabular}{|c|c|c|}
\hline \multicolumn{2}{|c|}{ Quintile-to-Quintile Transitions } \\
\hline Years & Overall Mobility Rate & $\begin{array}{c}\text { Mobility Rate out of } \\
\text { Bottom Quintile }\end{array}$ \\
\hline $1967-1976$ & $61 \%$ & $44 \%$ \\
\hline $1977-1986$ & $61 \%$ & $47 \%$ \\
\hline $1984-1994$ & $60 \%$ & $47 \%$ \\
\hline $1994-2004$ & $61 \%$ & $45 \%$ \\
\hline
\end{tabular}

Sources: Isabel V. Sawhill and Mark Condon, "Is U.S. Income Inequality Really Growing? Sorting out the Fairness Question," Policy Bites 13 (Urban Institute, 1992); Gregory Acs and Seth Zimmerman, "Like Watching Grass Grow? Assessing Changes in U.S. Intragenerational Economic Mobility over the Past Two Decades," (The Urban Institute and the Pew Economic Mobility Project, 2008), Table 1, p. 22. 


\section{Summary of Our Problems}

- Wages and income are stagnant or falling at the bottom

- Work rates for men are falling

- Marriage rates have been declining, especially among the poor

- Nonmarital birth rates have been increasing, especially among the poor

- Average wages and probably skills of $1^{\text {st }}$ and $2^{\text {nd }}$ generation immigrants have been declining

- Educational achievement is stagnant 
What To Do 


\section{Launch a Three-Front War}

- Improve Education

- Expand Work

- Strengthen Families 


\section{Personal Responsibility and Economic Success}

Income Class, by Adherence to Social Norms, 2007

\begin{tabular}{l}
\hline The Three Norms \\
-Complete high \\
school \\
-Work full time \\
-Wait until age 21 \\
and marry before \\
children
\end{tabular}
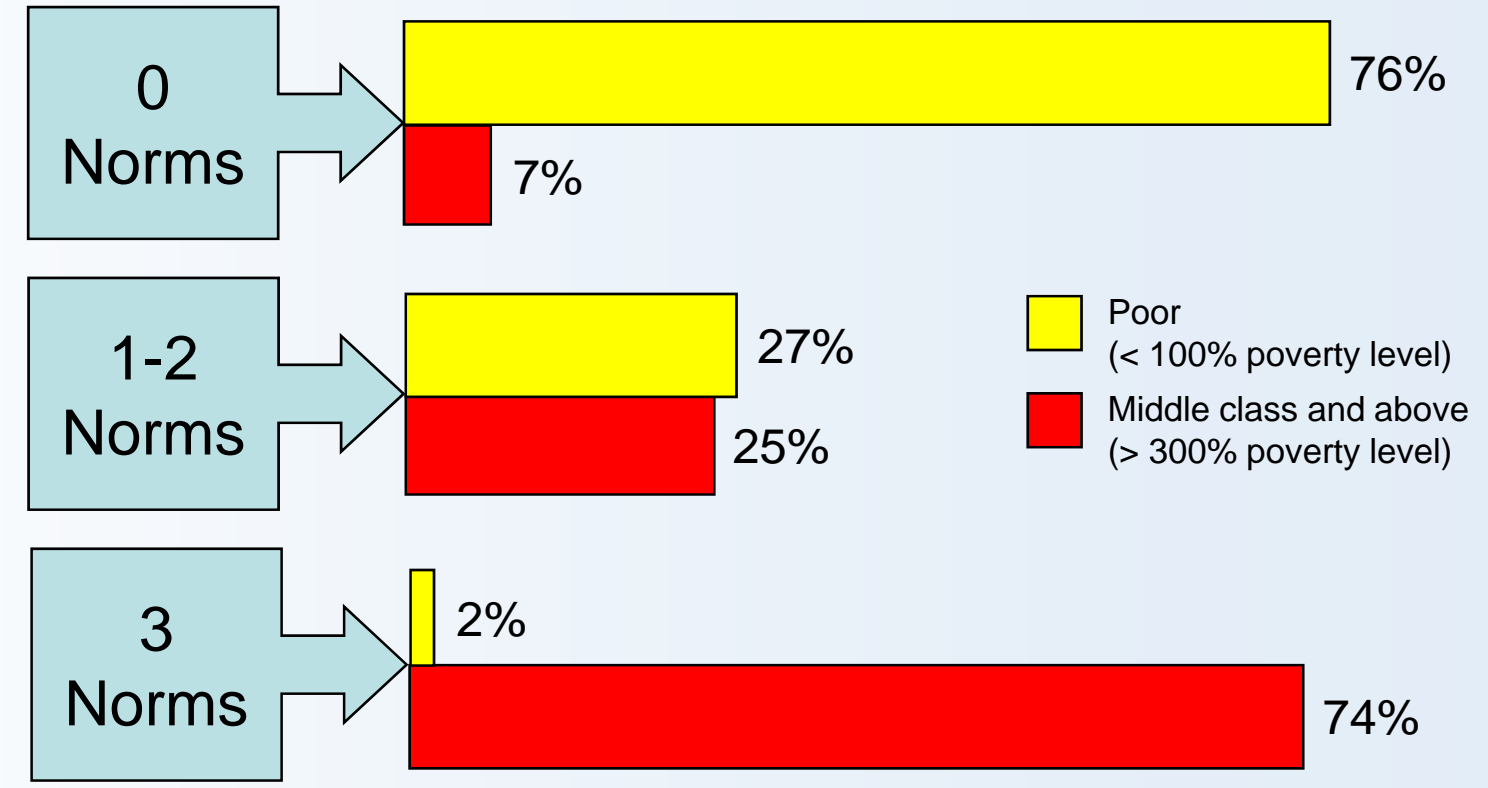


\section{Effectiveness of Five Factors in Reducing Poverty Rates}

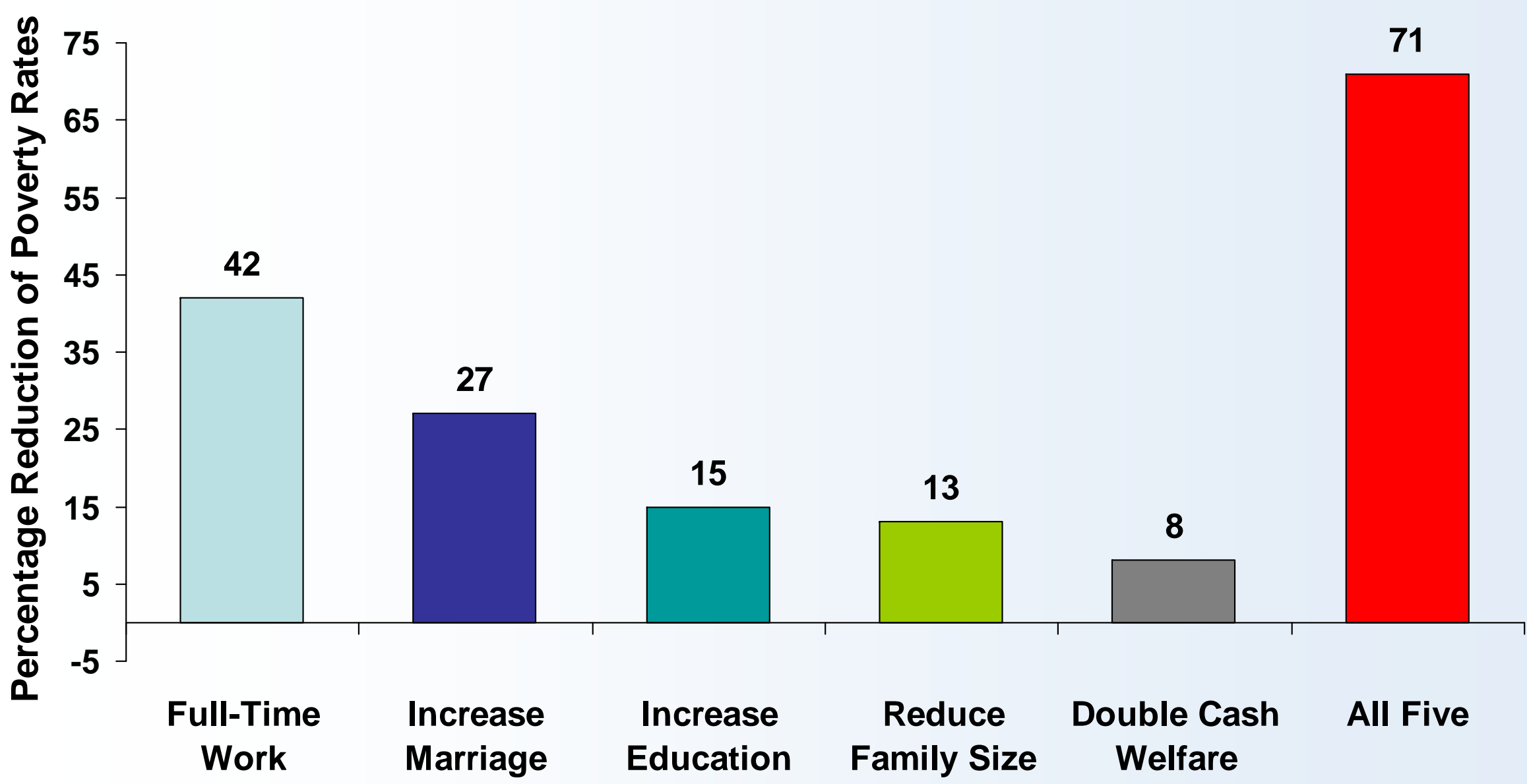

Based on Adam Thomas and Isabel V. Sawhill, "For Richer or for Poorer: Marriage as an Antipoverty Strategy," Journal of Policy Analysis Management 21, no. 4 (October 2002): 587-599; Ron Haskins and Isabel V. Sawhill, "Work and Marriage: The Way to End Poverty and Welfare," Welfare Reform and Beyond Policy Brief, The Brookings Institution (September 2003). 


\section{Strategy I: Give 'Em Money Poverty Among the Elderly, 1959 - 2008}

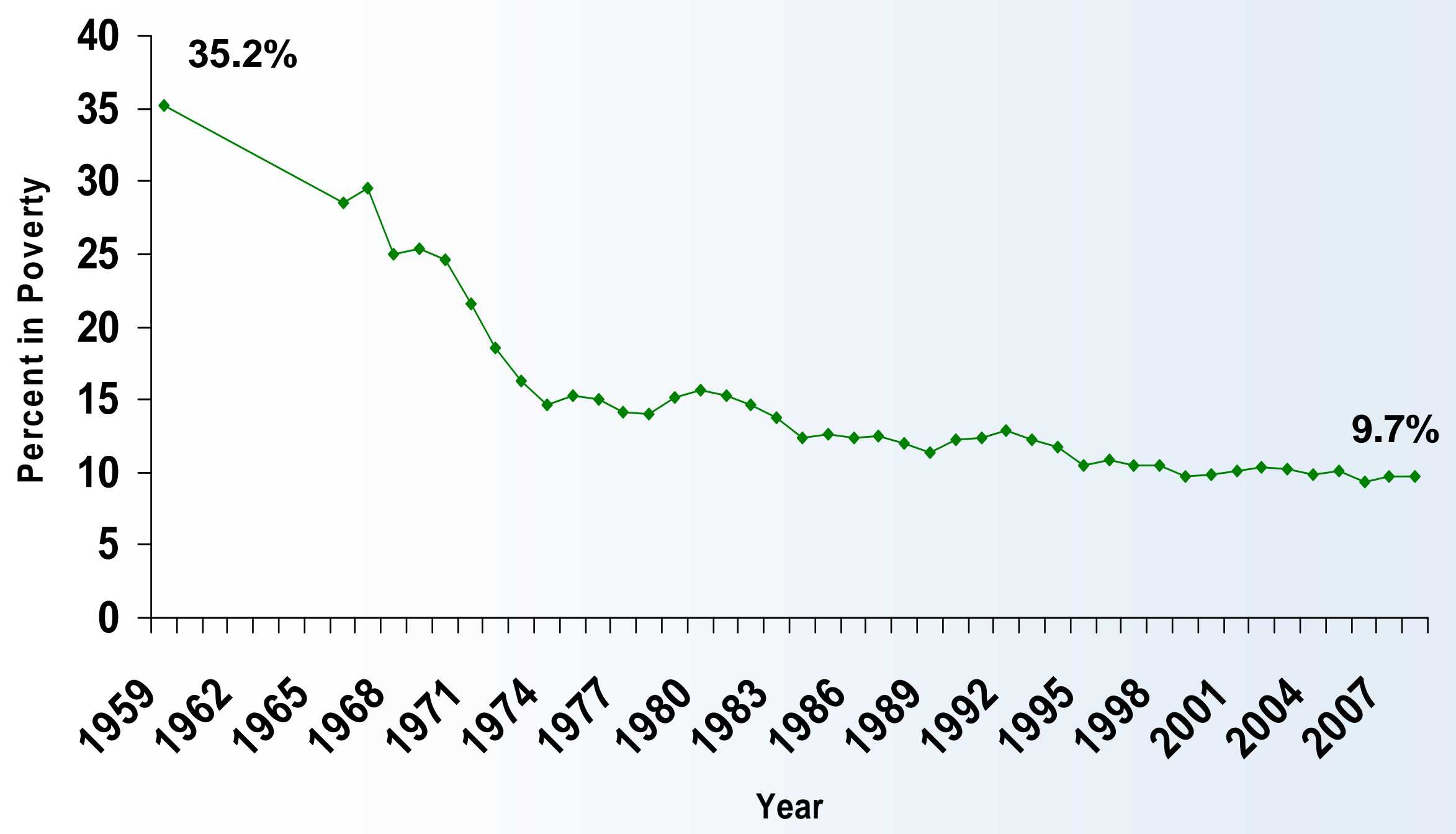




\section{Strategy II : Promote Work}




\section{Five Components of} Temporary Assistance for Needy Families

1. End Cash Entitlement

2. Block Grant Funding

3. Work Requirements

4. Sanctions

5. 5-Year Time Limit 


\section{AFDC/ TANF Caseload, 1962 - 2009}

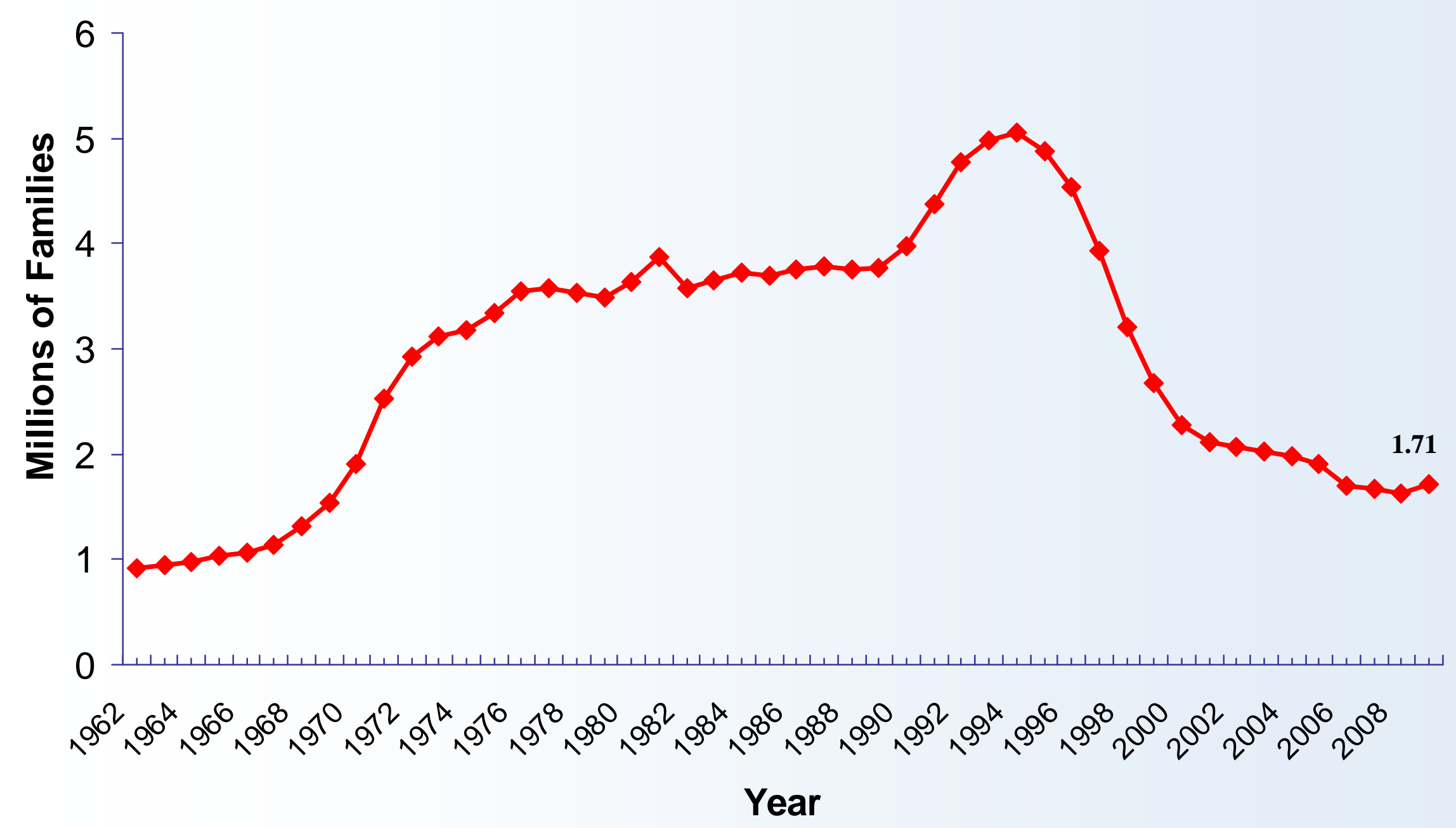

Sources: Congressional Research Service, U.S. Department of Health and Human Services,

http://www.acf.hhs.gov/programs/ofa/data-reports/caseload/caseload recent.html\#2007 (2002-2008), http://aspe.hhs.gov/HSP/indicators03/apa.htm\#ttanf1 $(1962-2001)$ 


\section{Employment-Population Ratio for All Single Mothers and Never-Married Mothers, 1980-2009}

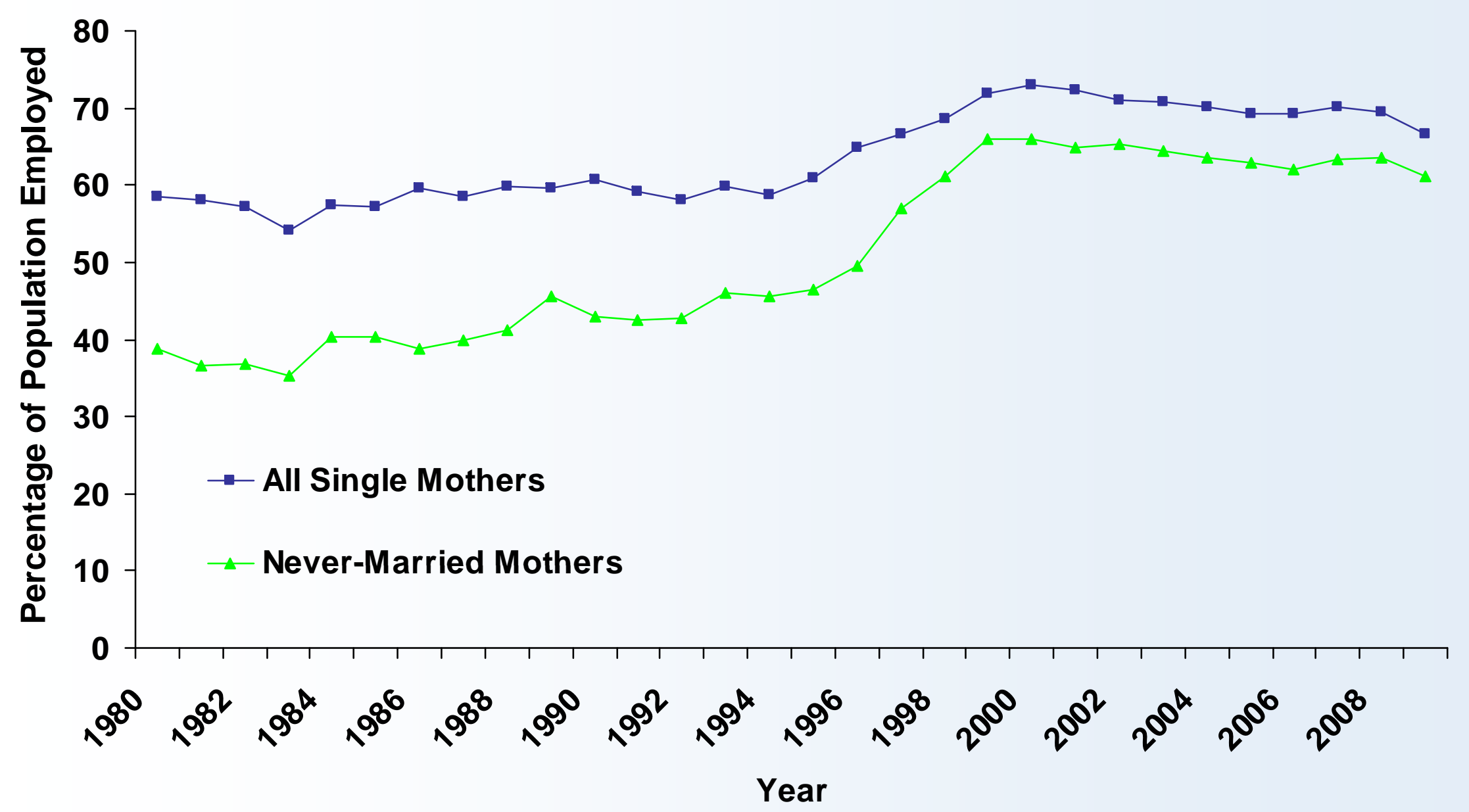


Earnings \& Means-Tested Benefits for Bottom Two Quintiles of Female Family Heads with Children, 1990 - 2007

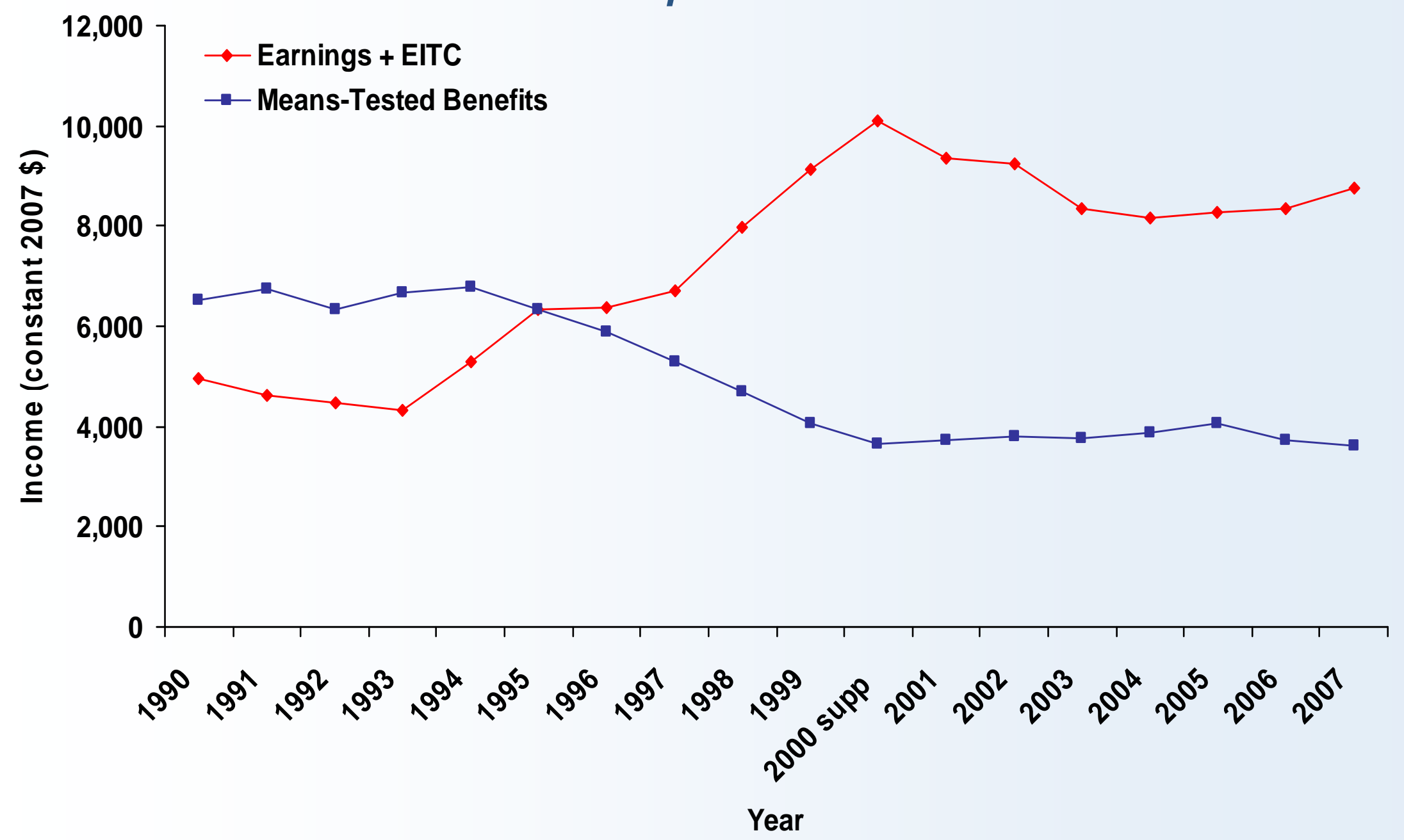


Poverty Rates for Black Children, Children in Female-Headed Households, and All Children

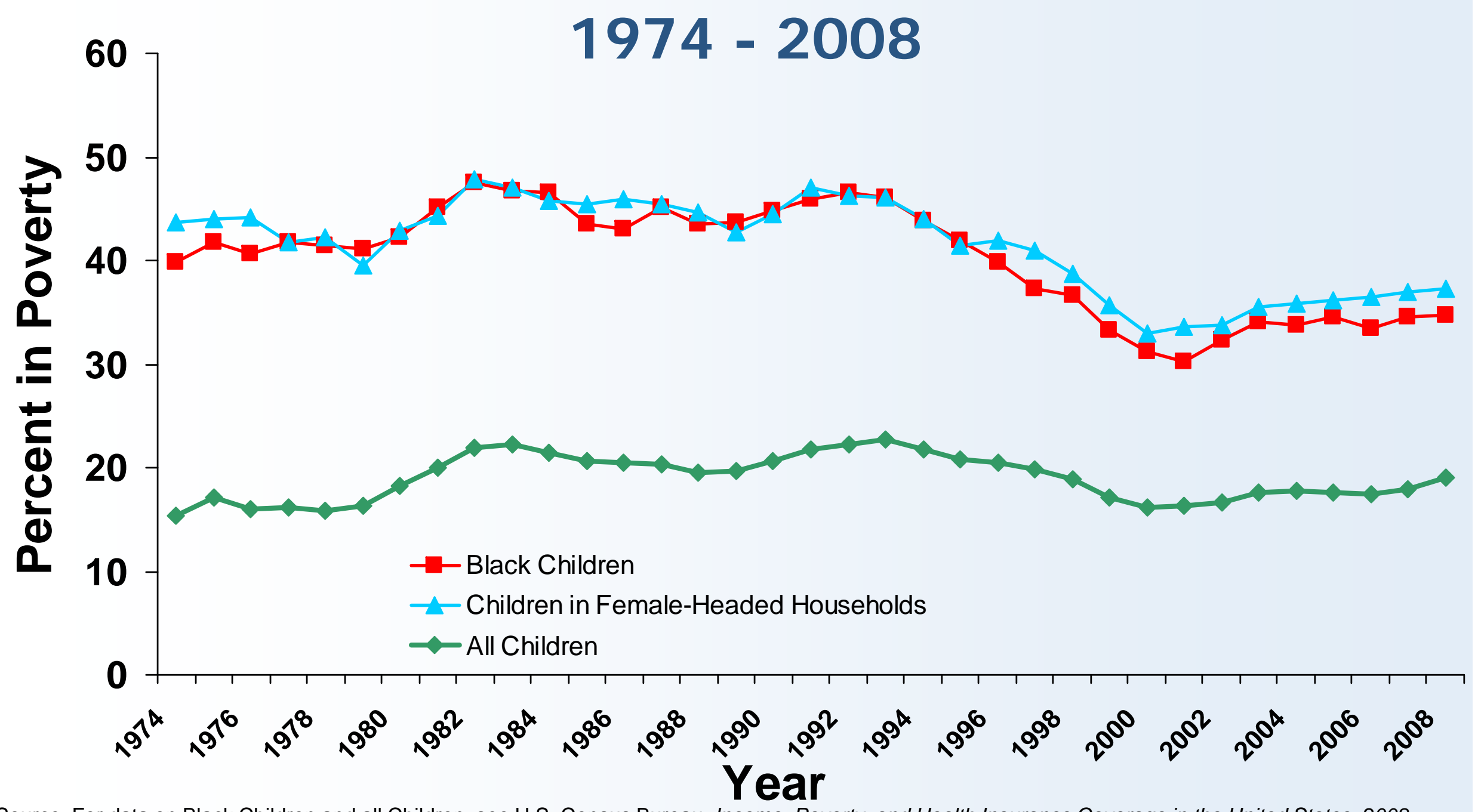

Source: For data on Black Children and all Children, see U.S. Census Bureau, Income, Poverty, and Health Insurance Coverage in the United States: 2008,

Table B-2; for data on Children in Female-Headed Households see, Poverty Status, by Type of Family, Presence of Related Children, Race and Hispanic Origin 1959 to 2008, Table 4 http://www.census.gov/hhes/www/poverty/histpov/famindex.html 


\section{Support for Working Families I ncreases Dramatically, 1984 - 1999}

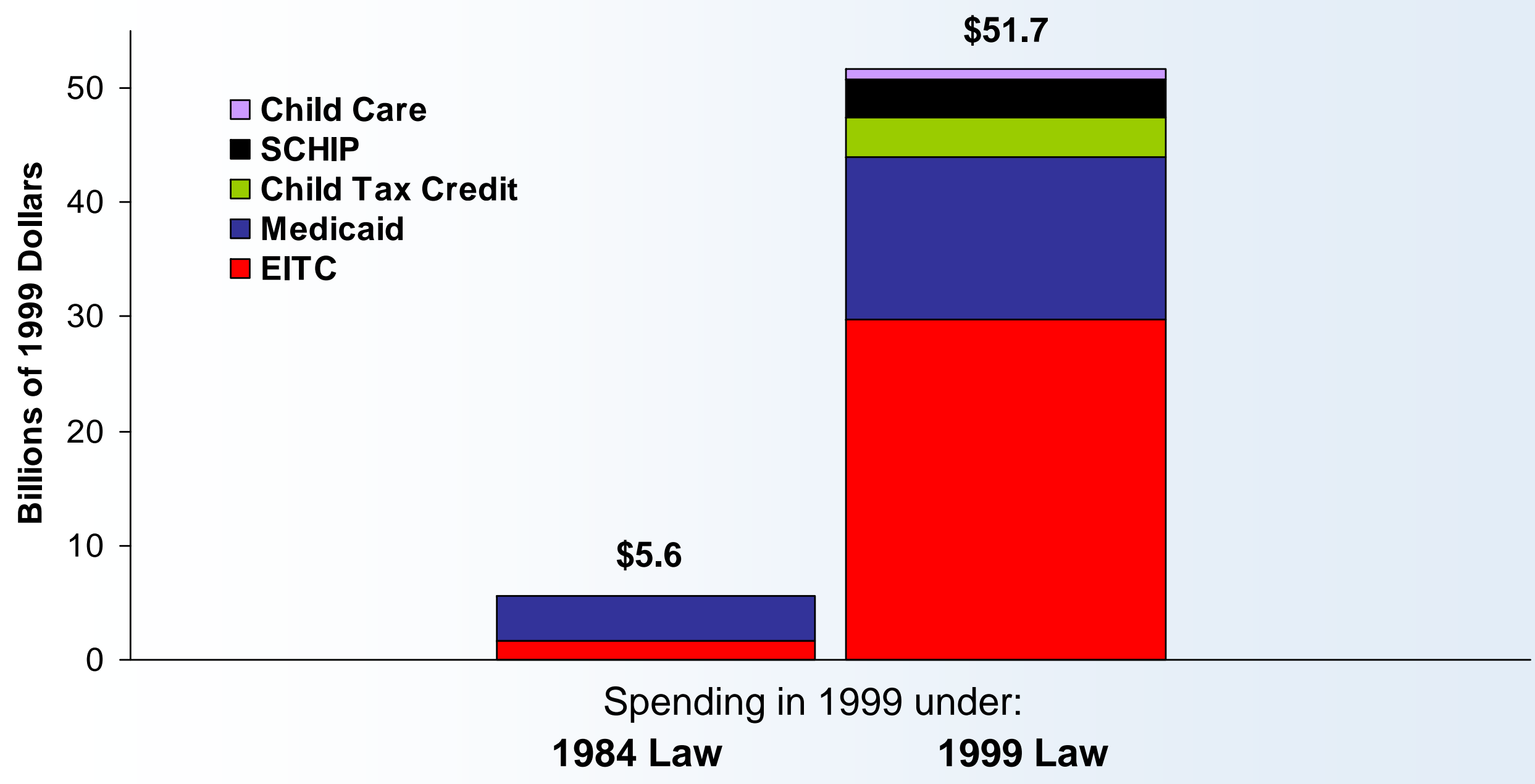

Source: Congressional Budget Office, Policy Changes Affecting Mandatory Spending for Low-Income Families Not Receiving Welfare, 1998. 


\section{An Agenda for I ncreasing Work to Reduce Poverty}

I. Increase Work Requirements:

- Food stamps

- Housing

II. Bring Back Industrial Arts in High School (Career Academies)

III. Strengthen the Work Support System:
- Day care
- Employment and training 
Strategy I I : Promote Education 


\section{Effects of Selected Early Childhood Programs on Adolescent and Adult Behaviors}

\begin{tabular}{lcc} 
Intervention and Outcomes: & $\begin{array}{c}\text { Control or } \\
\text { Comparison Group }\end{array}$ & $\begin{array}{c}\text { Group Receiving } \\
\text { Program }\end{array}$ \\
\hline Teenage Parenting Rates (Abecedarian) & 45 & 26 \\
Health problem (Perry Preschool) & 29 & 20 \\
Drug user (Abecedarian) & 39 & 18 \\
Needed treatment for addiction (Perry Preschool) & 34 & 22 \\
Abortion (Perry Preschool) & 38 & 16 \\
Number of felony violent assaults (Perry Preschool) & 0.37 & 0.17
\end{tabular}

Net Earnings Gain from Participating in Early Childhood Programs:

$\begin{array}{lc}\text { Abecedarian } & \$ 35,531 \\ \text { Perry Preschool } & \$ 38,892 \\ \text { Chicago Child-Parent Centers } & \$ 30,638 \\ \text { Head Start } & \text { No effect }\end{array}$

Note: Table entries are percentages unless otherwise noted.

Source: W. Steven Barnett and Clive Belfield, "Early Childhood Development and Social Mobility," The Future of Children 16, no. 2 (Fall 2006 ): 85. 


\section{Comparison of Selected Effect Sizes from Preschool Programs}

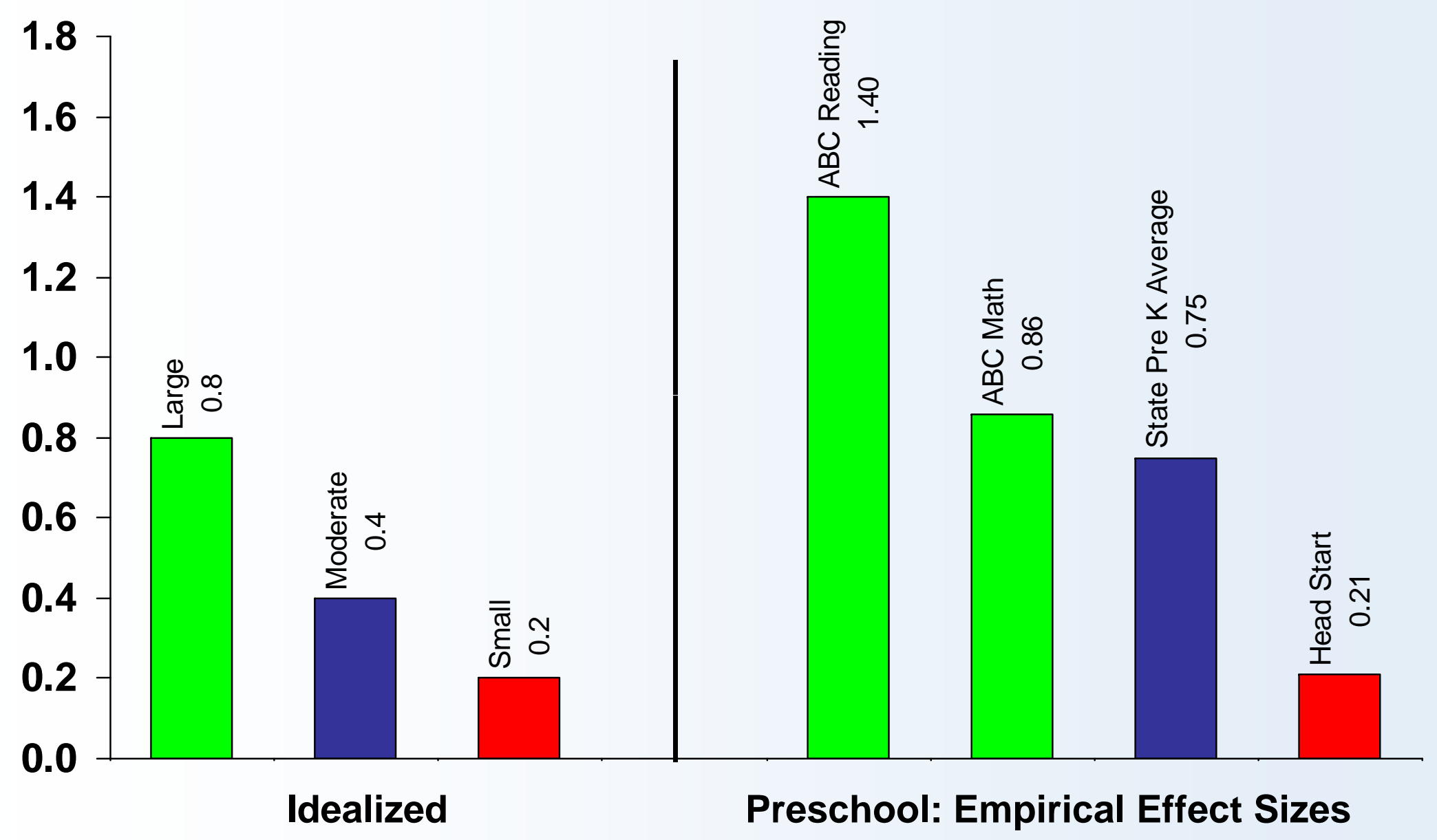




\section{Average Quality of Child Care Facilities in the U.S.}

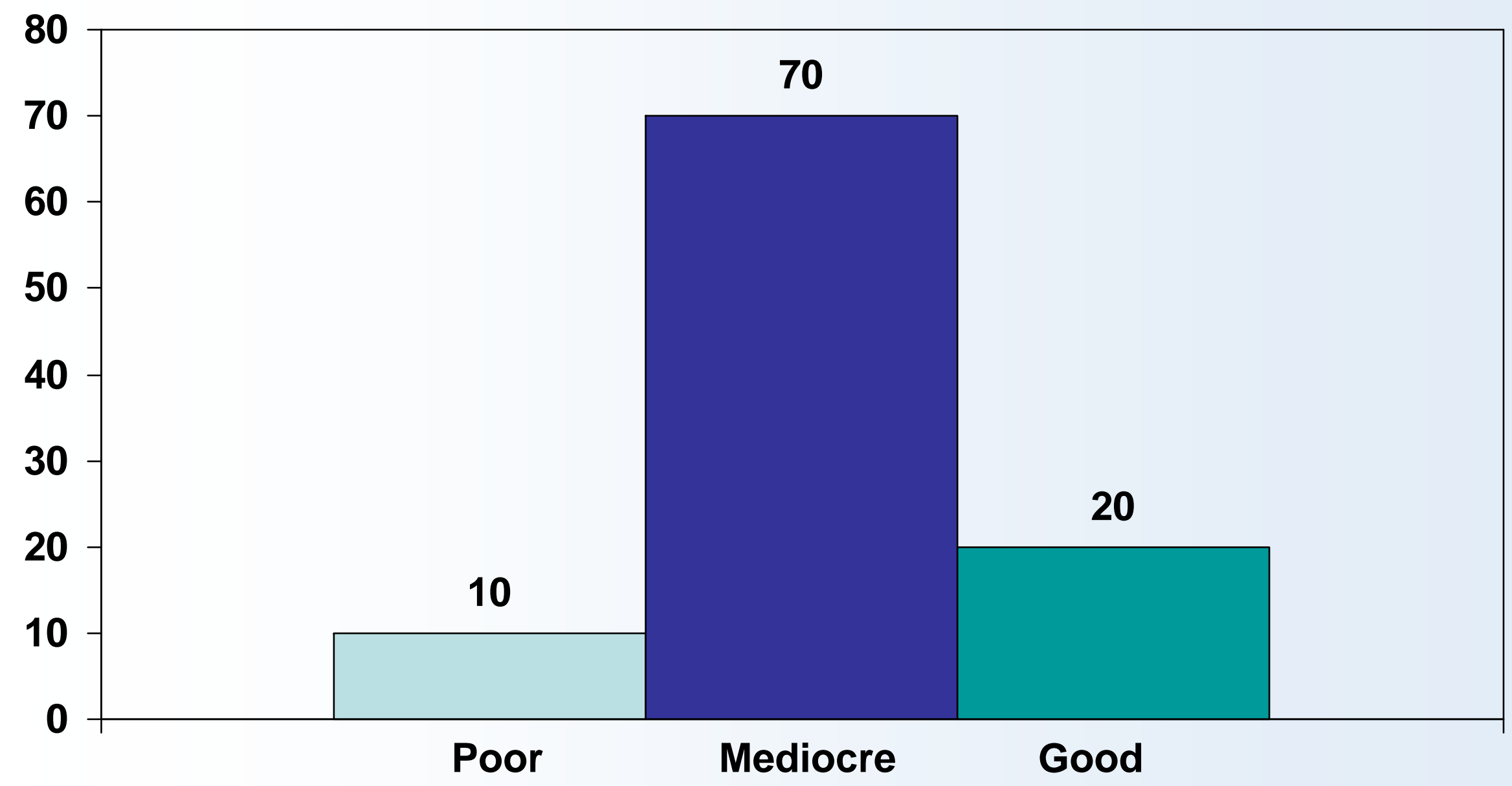




\section{Federal and State Spending, 2005}

Program

Cost (Billions)

\section{Day Care Programs}

Discretionary Child Care Development Fund (CCDF)

Mandatory CCDF

TANF transfers to CCDF

TANF direct child care

State CCDF Match and Maintenance of Effort (MOE)

TANF MOE in excess of CCDF MOE

Social Services Block Grant

0.2

Child and Development Care Credit (DCAPS)

0.8

Subtotal

$\$ 12.7$

\begin{tabular}{lc}
\multicolumn{1}{c}{ Preschool Education Programs } & $\$ 12.7$ \\
\hline Title I Grants to Local Education Agencies & 0.3 \\
Reading First (Reading Excellence before 2002) & 1.1 \\
Early Reading First & 0.1 \\
Special Education & 1.9 \\
Head Start & 7.0 \\
ces: U.S. Budget, Fiscal Year 2005; W. Steven Barnett and Others. 2003. The State of Preschool: & 3.0 \\
State Preschool Yearbook. New Brunswick, NJ: National Institute for Early Education Research, & Subtotal \\
gers University; W. Steven Barnett and others. 2006. The State of Preschool: State Preschool & $\$ 13.4$
\end{tabular}




\section{The Preschool Program We Need}

Goal: All Groups Enter School Performing at Average Level on Socioemotional and I ntellectual Measures

- Components:

- Home visiting

- Early education; 0-3

- Preschool program; 4

- School age follow-up

- Day Care

- $\quad$ Local Coordinating Group

- Integration of current funding streams

- Local standards/Federal standards

- Competition and parent choice

- Teacher Quality

- Testing; Especially at school entry 


\section{Strategy I V: Strengthening Marriage}

- Reduce nonmarital births (including to teens)

- Increase marriage rates 


\section{Ten Characteristics of Effective Teen Pregnancy Prevention Programs}

- $\quad$ Focus on one or more sexual behaviors that lead to unintended pregnancy

- Employ behavioral goals, methods, and materials appropriate for the age, sexual experience, and culture of the students

- Theory-based programs with evidence of impacts on risky behaviors

- Sufficient length of program

- Consistent emphasis on messages about abstaining from sex or using condoms

- Multiple teaching methods (not just lecture)

- Provide accurate information about risks of pregnancy and methods of avoiding

- Address social pressures to have sex

- Teach and practice refusal skills

- Teachers believe in program 


\section{Bush Administration Marriage I nitiatives}

- Marriage education included in several existing programs (child protection, Head Start, refugee)

- Separate initiatives for Hispanic and Black marriage

- Research and Demonstration:

- Building Strong Families

- Supporting Healthy Marriage

- Community-Wide Initiatives 


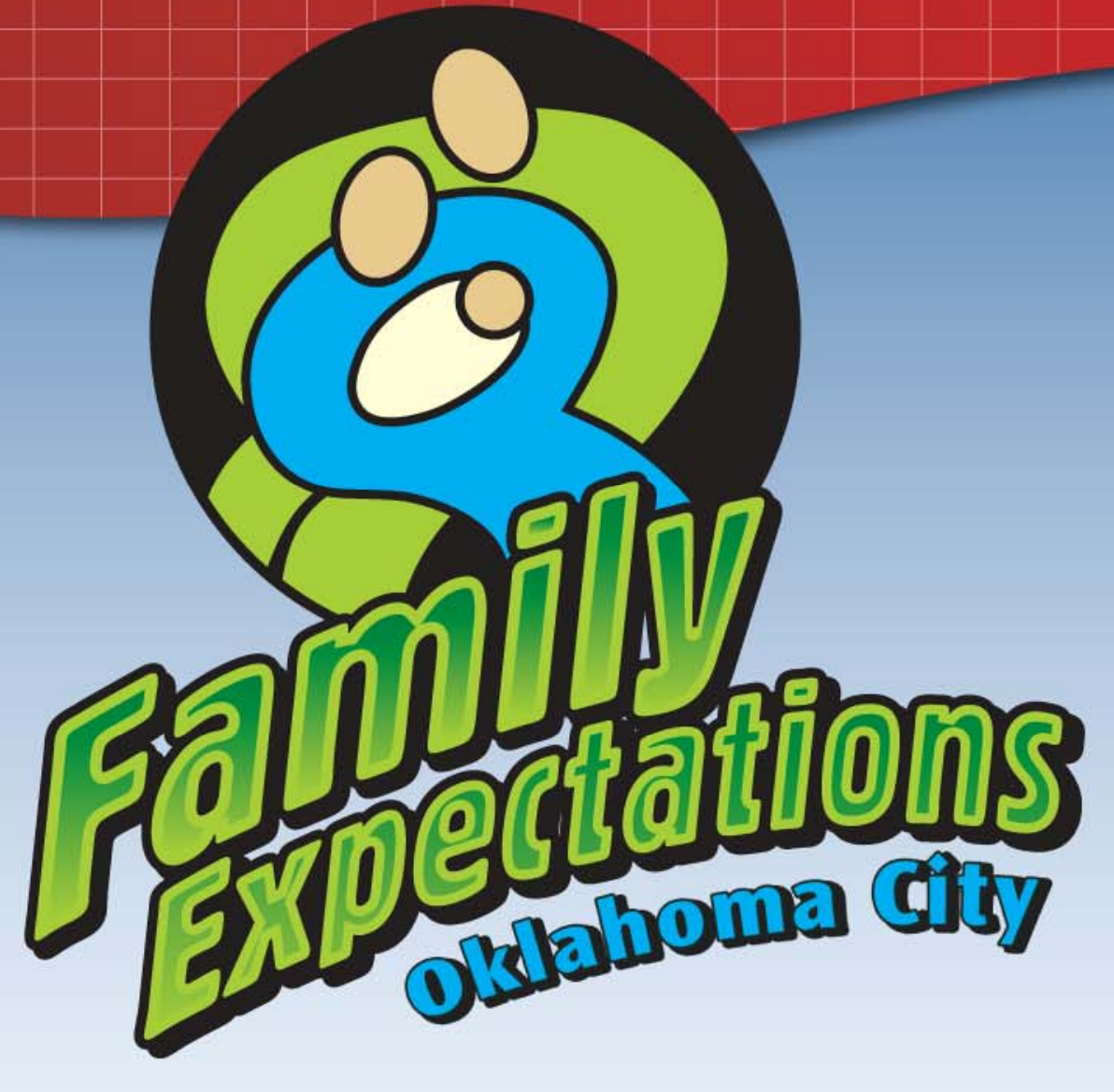

A program that strengthens couple relationships and prepares both parents for the transition to parenthood 


\section{Who Participates in FE?}

- Both Unmarried and Married couples, where the mom is currently pregnant or the baby is 3 months of age or younger (at enrollment)

- Both mom and dad separately consent to participate in the program and they have to assert that they intend to stay together, and are available, to participate in a year-long program

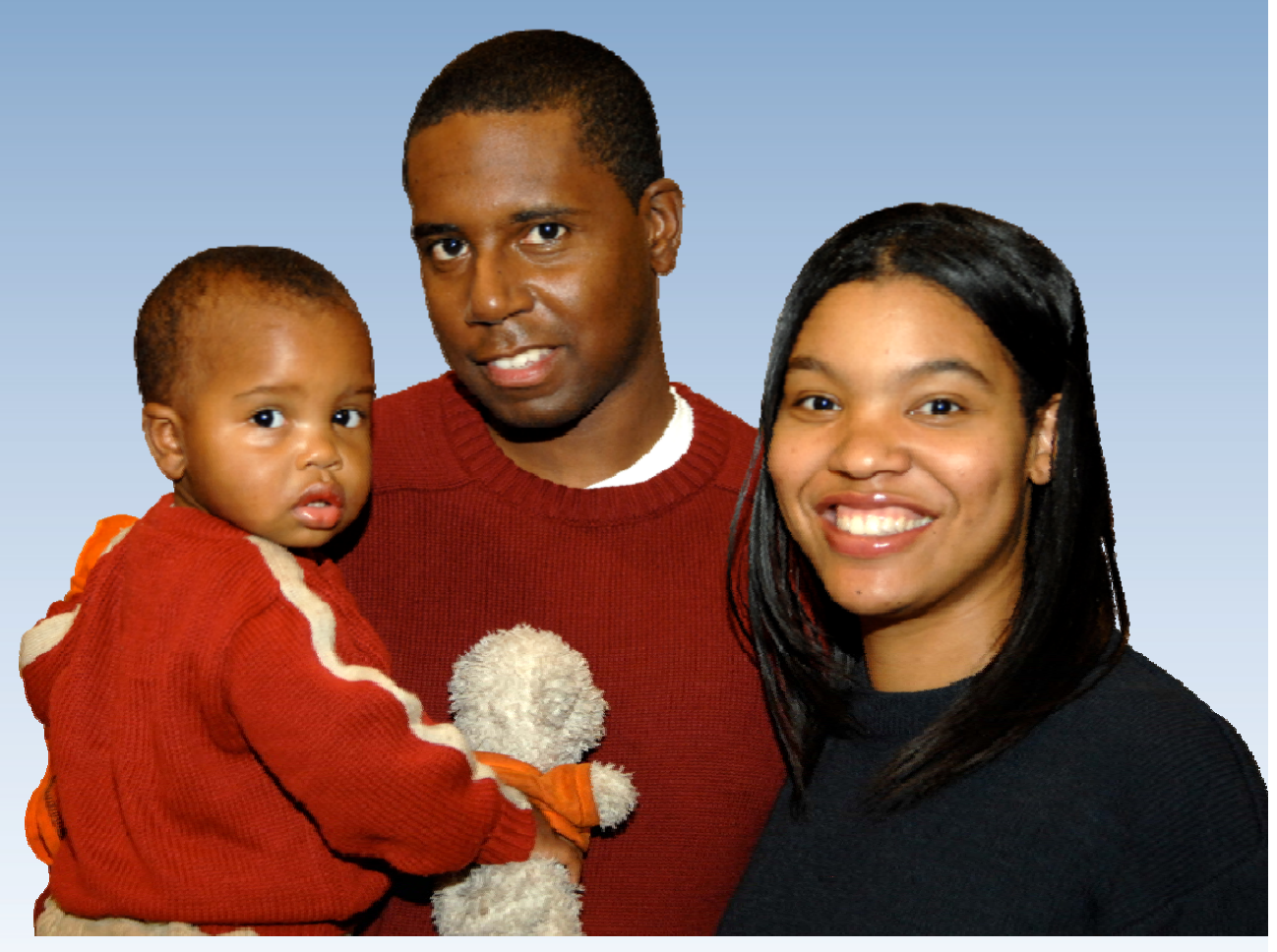




\section{Who Participates in FE?}

- Financially Vulnerable Families: the majority of FE parents are funding their birth with Medicaid, so their income is $200 \%$ of poverty or less

- Couples where Mom does not disclose domestic violence issues that would result in the couple being screened out of the program
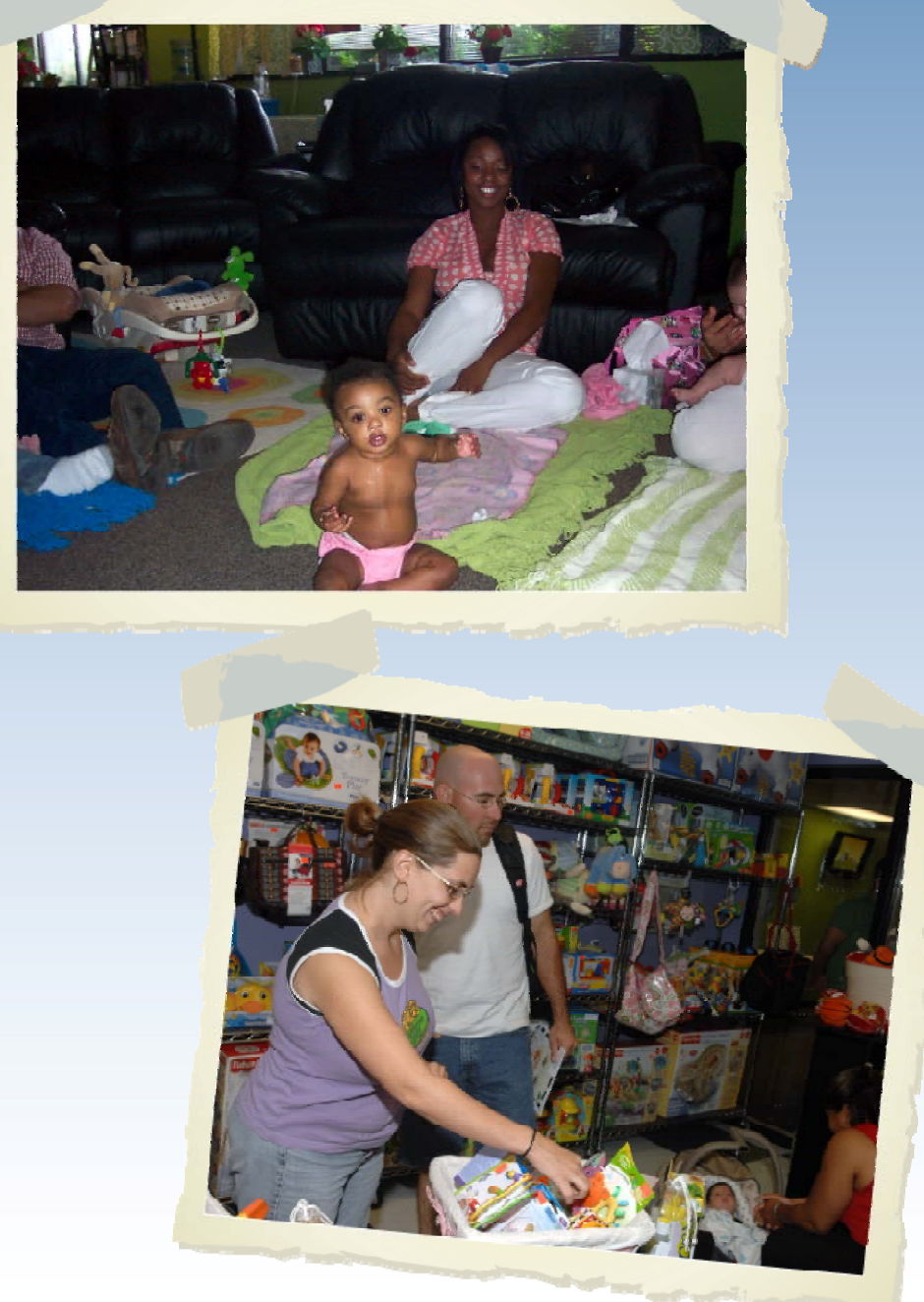


\section{What Does It Mean For Couples To Participate In FE?}

\section{They attend workshops!}

- Learn Skills to Strengthen Their Relationships

- Get Information About The Baby's First Months of Life

- Connect with Other Couples

- 30 Hours of Core Curriculum

- Additional Workshops To Build Their Family Tool Box (parenting, finances, early childhood education)
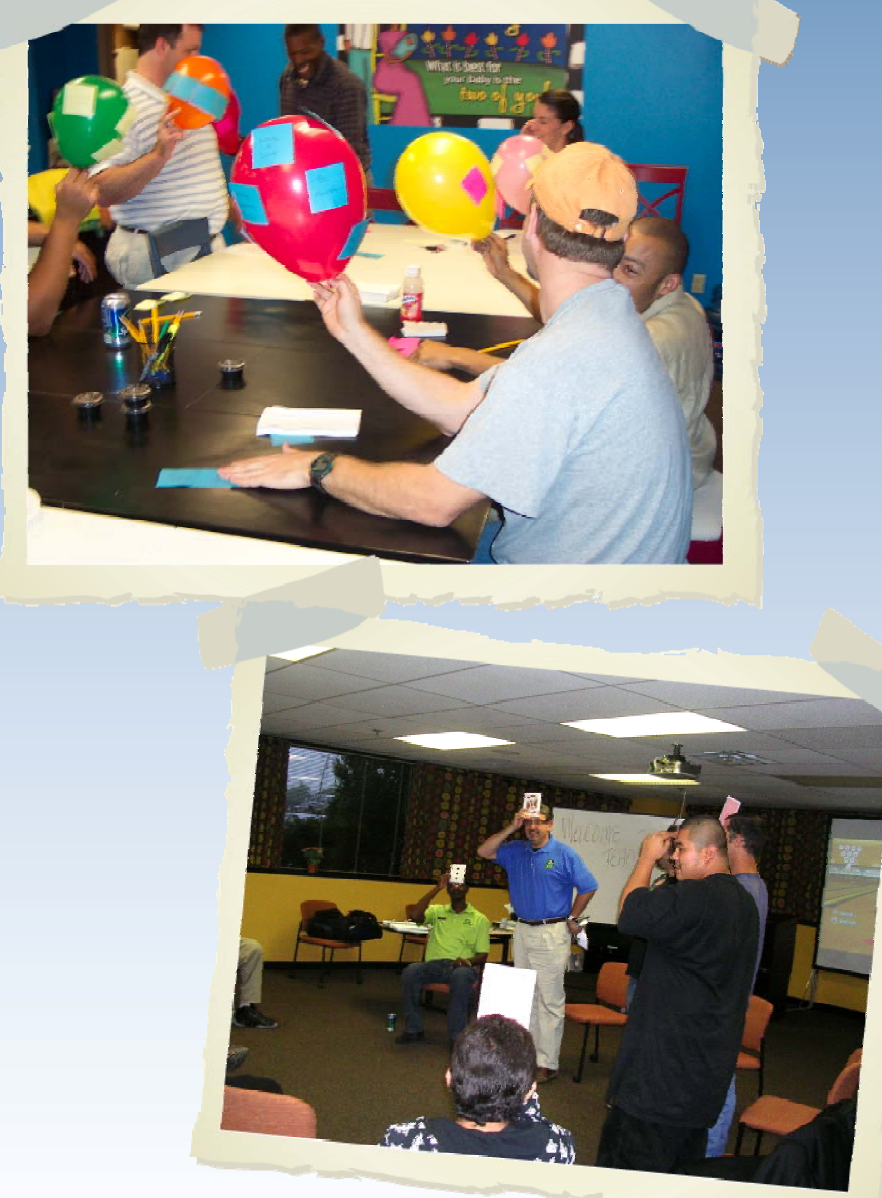


\section{What Does It Mean For Couples to Participate $\ln$ FE?}

They Have A Family Support Coordinator!

- Participate in Regular 1 on 2 Meetings

- Receive Resources To Meet Family Needs

- Receive Referrals To Other Community Resources

- Set, Work Toward and Achieve Family Goals

- Practice Skills Learned In Workshops
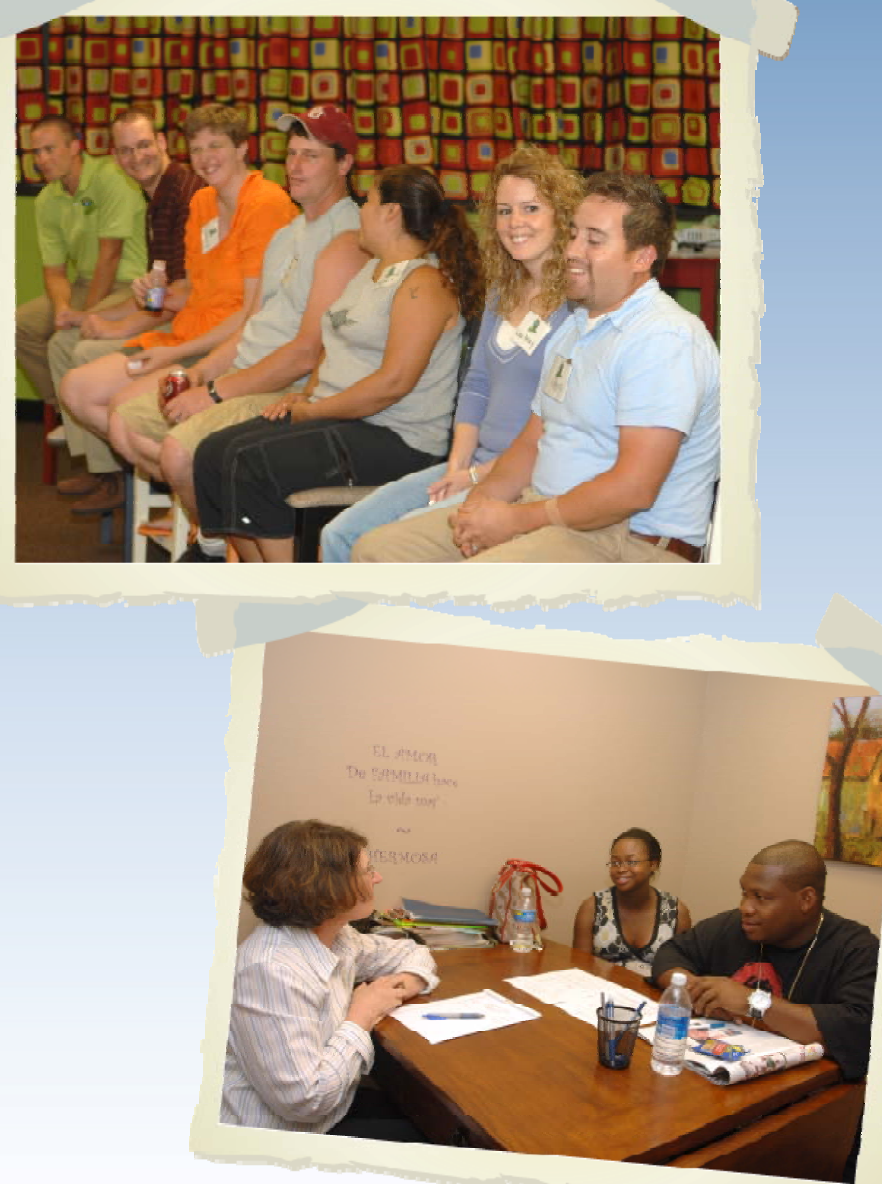


\section{What Does It Mean For Couples To Participate}

In FE?

They Spend Time Together and With Peers!

- Date Nights

- Community Outings

- Holiday Events

- Moms' and Dads' Groups
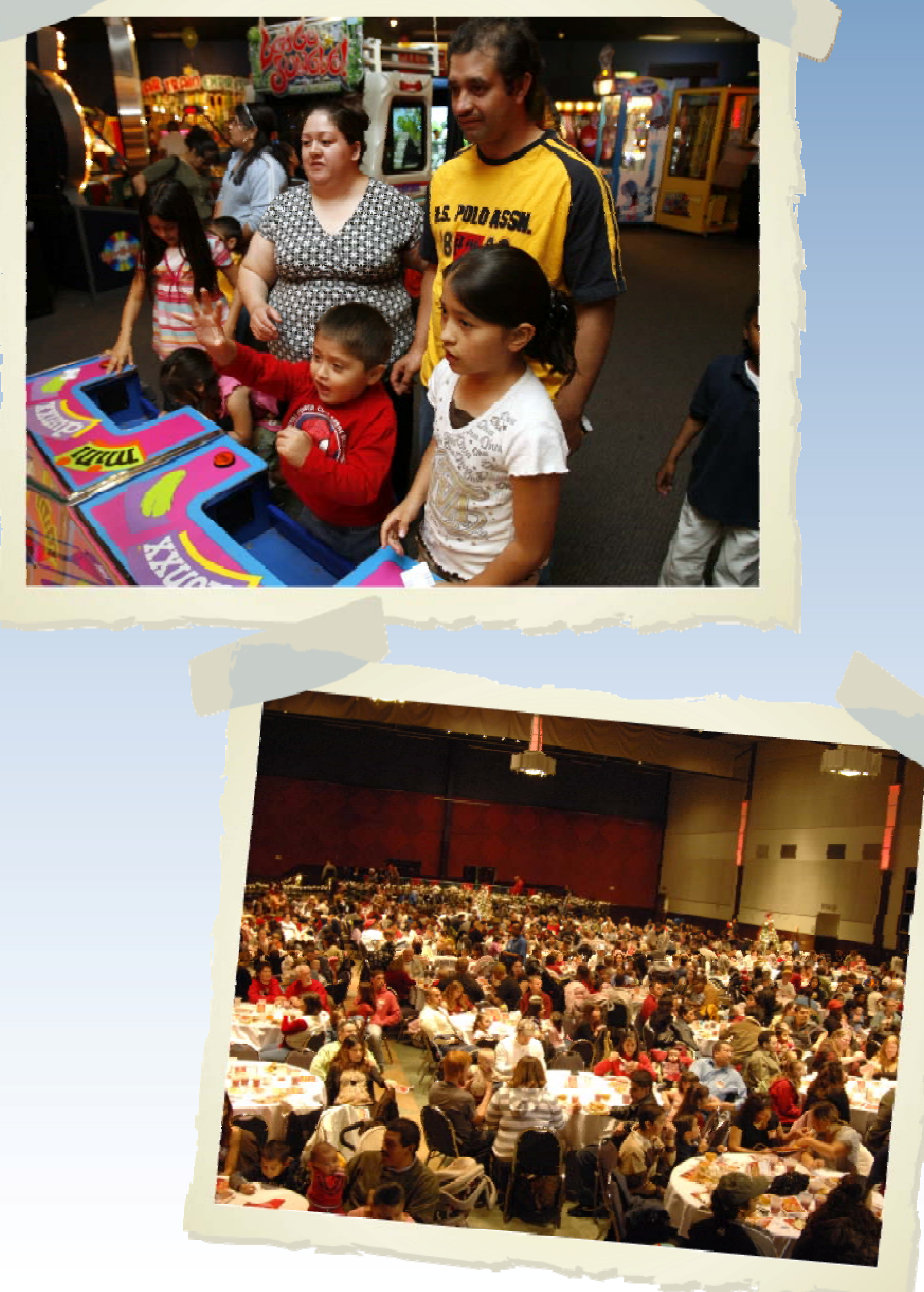


\section{FE By The Numbers}

- 2,452 couples have participated since 2005 , currently about 670 couples currently enrolled

- 1,800 parents and children attended the 2009 FE holiday party

- 745 workshops and/or extended activities since Aug 2005

- In 2009, over 29,000 hours of direct service hours with couples

- 2,000 couples enrolled in two national random assignment studies - researchers will be evaluating the effect of the program on parents and children over the next five years 


\section{A Final Word From FE Participants}

"My family has been involved in countless programs over the years, and this is the first time l've been treated like I'm a part of my family." - FE Dad

"We look back on the first couple of years of our relationship and just laugh and say, 'What exactly was the problem?' It's so strange because all we needed were the tools to communicate, which we got through Family Expectations." - FE Mom

"We love the atmosphere and the cool setting for workshops and office visits. We always feel like everyone is glad that we are here. We don't feel judged when we walk through the door. We just love to come....and the information we are learning through Family Expectations is helping equip us to be good partners and parents." - FE Dad 


\section{Well-Being of Adolescents Aged Twelve to Eighteen, 2002 Estimates}

\begin{tabular}{|l|c|c|c|c|}
\hline \multirow{2}{*}{ Problem } & 2002 & \multicolumn{2}{|c|}{ Estimated change based on two-parent families in: } \\
\cline { 3 - 5 } & Estimate & 1980 & 1970 & 1960 \\
\hline Repeated Grade & $6,948,530$ & $-299,968$ & $-643,264$ & $-746,587$ \\
\hline Suspended from school & $8,570,096$ & $-485,165$ & $-1,040,410$ & $-1,207,523$ \\
\hline Delinquency & $11,632,086$ & $-216,498$ & $-464,269$ & $-538,841$ \\
\hline Violence & $11,490,072$ & $-211,282$ & $-453,082$ & $-525,857$ \\
\hline Therapy & & & $-531,392$ & $-616,745$ \\
\hline Smoked in last month & $3,412,678$ & $-247,799$ & $-514,611$ & $-597,269$ \\
\hline Thought of suicide & $5,083,513$ & $-239,974$ & $-178,995$ & $-207,746$ \\
\hline Attempted suicide & $3,692,358$ & $-83,469$ & $-61,350$ & $-71,413$ \\
\hline
\end{tabular}

Source: Paul R. Amato, "The Impact of Family Formation Change on the Well-Being of the Next Generation" The Future of Children 15, no. 2 (Fall 2005): Table 2. 


\section{BROOKINGS MOUNTAIN WEST}

BROOKINGS

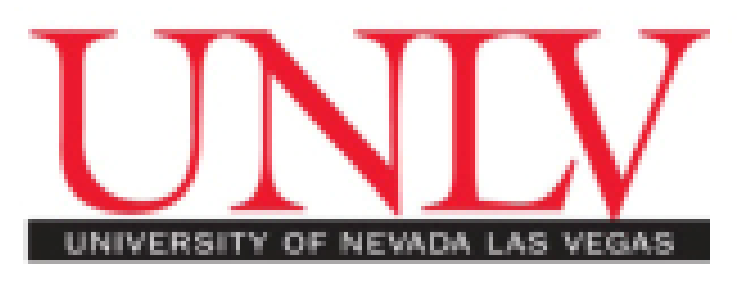

